\title{
Acute stress alters transcript expression pattern and reduces processing of proBDNF to mature BDNF in Dicentrarchus labrax
}

\author{
Chiara Tognoli', Federica Rossi', Francesco Di Cola², Gabriele Baj², Enrico Tongiorgi², Genciana Terova', \\ Marco Saroglia', Giovanni Bernardini ${ }^{1,3}$, Rosalba Gornati ${ }^{1,3^{*}}$
}

\begin{abstract}
Background: Stress involves alterations of brain functioning that may precipitate to mood disorders. The neurotrophin Brain Derived Neurotrophic Factor (BDNF) has recently been involved in stress-induced adaptation. BDNF is a key regulator of neuronal plasticity and adaptive processes. Regulation of BDNF is complex and may reflect not only stress-specific mechanisms but also hormonal and emotional responses. For this reason we used, as an animal model of stress, a fish whose brain organization is very similar to that of higher vertebrates, but is generally considered free of emotional reactions.
\end{abstract}

Results: We provide a comprehensive characterization of BDNF gene in the Dicentrarchus labrax and its transcriptional, translational and post-translational regulation following acute stress. While total BDNF mRNA levels are unchanged, BDNF transcripts $1 \mathrm{c}$ and $1 \mathrm{~d}$ resulted down regulated after acute stress. Acute stress induces also a significant increase in proBDNF levels and reduction in mature BDNF suggesting altered regulation of proBDNF proteolytic processing. Notably, we provide here the first evidence that fishes possess a simplified proteolytic regulation of BDNF since the pro28Kda form, generated by the SKI-1 protease in mammals, is absent in fishes because the cleavage site has first emerged in reptilians. Finally, we show that the proBDNF/totBDNF ratio is a highly predictive novel quantitative biomarker to detect stress in fishes with sensitivity $=100 \%$, specificity $=87 \%$, and Negative Predictive Value $=100 \%$.

Conclusion: The high predictivity of proBDNF/totBDNF ratio for stress in lower vertebrates indicates that processing of BDNF is a central mechanism in adaptation to stress and predicts that a similar regulation of pro/ mature BDNF has likely been conserved throughout evolution of vertebrates from fish to man.

\section{Background}

Brain Derived Neurotrophic Factor (BDNF) is the most abundant and widely expressed neurotrophin, a family of structurally related proteins required for the development and function of the vertebrate nervous system [1-3]. In the vertebrate brain, BDNF also governs longlasting changes in synaptic efficacy and morphology [3-8]. Recent studies have suggested that BDNF may be involved in stress-induced adaptation in adult [9]. Indeed, several types of injury and cell stress affect the expression of BDNF in the mammalian brain; in

\footnotetext{
* Correspondence: rosalba.gornati@uninsubria.it
'Department of Biotechnology and Molecular Science, University of Insubria,

*Correspondence: rosalba.gornati@uninsubria.it
'Department of Biotechnology and Molecular Science, University of Insubria, Varese-Italy
} varese taly

particular, chronic stress decreases the synthesis of hippocampal BDNF [10-13] while acute stress induces complex alterations in the expression of BDNF, including a decrease in the hippocampus and an increase in the prefrontal cortex [14-17].

"Stress" is a biological term which refers to the consequences of the failure of a human or animal body to adequately answer to environmental stimuli. Stress induction is also used to study alterations of brain functioning leading to mood disorders which are often precipitated or exacerbated by acute or chronic stressful life events [18-20]. Of note, stress involves subjective feelings and experience of pleasure, pain, frustration, hunger or other states, and is therefore often difficult to define and measure [21]. This is particularly complicated in 
mammals and primates in which the emotional components may have a dominant effect. Since alterations in BDNF expression were also found in response to emotions such as anxiety or fear in rodents [22] and BDNF affects emotional preferences in humans [23], it remains to be determined how the stress itself or the associated behavioral responses contribute in mediating these changes. In this view, it is interesting to use as an animal model of stress, a fish whose brain organization is very similar to that of higher vertebrates, but is generally considered free of emotional reactions.

Stress conditions were traditionally evaluated by monitoring blood levels of cortisol, hemoglobin, and glucose [24], but these descriptors may not be sufficiently reliable when chronic stresses are applied and animal welfare is concerning [25]. It is therefore necessary to search for further parameters, which are capable to describe, taking into account the "allostatic concept" [26] biological stress and animal emotional responses. This point is particularly important when monitoring welfare of animals reared for commercial interest. In fact, production and quality have to be equally improved with benefits on the public perception of the products and consequent positive repercussions on marketing aspects. Accordingly, we started a search of alternative molecular biomarkers of stress. Besides the classical stress-related genes such as metallothioneins (MT), heat shock proteins (HSP), 3-hydroxil-3-methyl-glutaryl coenzymes A reductase (HMGCR) [27,28], enolase, Na ${ }^{+} / \mathrm{H}^{+}$exchanger (NHE)-1 c-Fos, glucocorticoid receptor (GR), glucose transporter (GLUT2) [29-32], plus genes related to specific stress conditions, as oxygen fluctuation (HIF-1 $\alpha$ ) and food deprivation [33-35], we decided to consider also neurobiological markers such as BDNF.

Accordingly, we investigated the effects of acute stress on BDNF expression in Dicentrarchus labrax. We report the genomic organization of D. labrax BDNF and its transcripts-specific expression pattern during posthatching development. In addition, we analyzed BDNF expression in adult tissues, and post-translational processing in response to a well standardized type of acute stress such as water deprivation.

\section{Methods}

\section{Animals}

European seabass eggs, at stage of somites formation, were obtained from a commercial hatchery on Crete. The eggs were incubated in three 500 L-cylindriconical polyester tanks ( 50,000 eggs/tank) at the Institute of Aquaculture of the Hellenic Center for Marine Research (Heraklion, Crete). During the autotrophic stages (complete absorption of lecith reserves) larvae were kept in darkness. The oxygen level was maintained at about 7 $\mathrm{mg} / \mathrm{L}$ throughout the experimental period.
Following mouth opening and eye development, the larvae under intensive conditions are exposed to low light intensity (5-10 lux) without food for a period of 24 days until swim bladder is fully inflated. Only when inflated swim bladder is observed in more than $80 \%$ of the population, larvae were fed using an automatic feeding system. Ten larvae were taken every day for determining the morphological characteristic and total length.

The general conditions of rearing are presented in the Table 1, while the modality of the sampling, carried out in November 2008, are reported in Table 2. Pools of larvae for each developmental stage were randomly sampled and weighted. The samples were stored in RNAlater (Ambion, Austin, TX, USA) and kept at $-20^{\circ} \mathrm{C}$ until the molecular biology analysis.

Fingerling seabass were obtained from Nuova Azzurro $^{\circ}$ hatchery in Civitavecchia (RM, Italy), and reared into three fiberglass raceway tanks with $2.5 \mathrm{~m}^{3}$ water each, with inconsistent mortality, at low biomass density $\left(<10 \mathrm{Kg} / \mathrm{m}^{3}\right)$. The tanks were connected to a water recirculation system where salinity (obtained adding salt Oceanfish 600 LT from Prodac Int ${ }^{\oplus}$ to dechlorinated tap water) was $20 \mathrm{~g} / \mathrm{l}$. Other water conditions were: temperature $21 \pm 1^{\circ} \mathrm{C}, \mathrm{pH} 8.2$, total ammonia $<0.2$ $\mathrm{mg} / \mathrm{l}$; dissolved oxygen was maintained over $99 \%$ of the saturation, by insufflating pure $\mathrm{O}_{2}$ to the system. At average weight of $450 \mathrm{~g}$ (adult animals), two groups of five animals were randomly sampled. The first group (control) was rapidly killed by severing the cervical column; brain, liver, kidney and muscle were removed, frozen in liquid $\mathrm{N}_{2}$ and stored at $-80^{\circ} \mathrm{C}$ for molecular biology analysis. The second group (stressed) was kept for 30 minutes in a water deprivation condition (water volume of $20 \mathrm{~L}$ in a bucket $50 \times 50 \times 50 \mathrm{~cm}$ ), then tissues were removed as described above.

The experimental protocol of this study was approved by the Ethics Committee of the University of Insubria Isolation and amplification of genomic DNA

Genomic DNA was extracted from $25 \mathrm{mg}$ of liver with DNeasy Blood \& Tissue Kit (Qiagen, Milan, Italy) according to the manufacturer's procedure.

Introns were amplified with primers designed in proximity of putative exon/intron junctions, inferred comparing ortologue sequences of BDNF (Genomic PCR section). All primers used in this paper are reported in Table 3. The PCRs were set using $500 \mathrm{ng}$ of genomic DNA, Herculase Enhanced DNA Polymerase 5 $\mathrm{U} / \mu \mathrm{l}$ (Stratagene, La Jolla, CA, USA) in its own buffer. The couple of primers used were Dl_ex1beta_fw and Dl_ex1a_rev, Dl_ex1a_fw and Dl_ex1c_rev, Dl_ex1c_fw and D1_P2_ant_BDNF. The reactions were incubated in a thermal cycler at the conditions suggested in the manufacturer's procedure. PCR fragments were run on a $0,7 \%$ agarose gel, stained with ethidium bromide and 
Table 1 conditions of rearing

\begin{tabular}{|c|c|c|c|c|c|}
\hline & INTENSIVE & & & & \\
\hline $\begin{array}{l}\text { Season of } \\
\text { rearing }\end{array}$ & Winter - Spring & & & & \\
\hline $\begin{array}{l}\text { Density of } \\
\text { eggs }\end{array}$ & 100 egg | $\left.\right|^{-1}$ & & & & \\
\hline Water quality & $\begin{array}{l}\text { Tank filled with filtered } \\
\text { sea water from deep } \\
\text { drill }\end{array}$ & $\begin{array}{l}\text { Renewal from } \\
\text { biological filter }\end{array}$ & $\begin{array}{l}\text { Pseudogreen } \\
\text { water } \\
\text { method }\end{array}$ & Closed recirculation system & $\begin{array}{l}\text { Controlled } \\
\text { temperature } \\
\text { and light }\end{array}$ \\
\hline $\begin{array}{l}\text { Temperature } \\
\text { range }\end{array}$ & Constant $17,5 \pm 1^{\circ} \mathrm{C}$ & & & & \\
\hline $\begin{array}{l}\text { Water } \\
\text { renewal rate }\end{array}$ & $\begin{array}{l}\text { Initially } 10 \% \mathrm{~h}^{-1} \text {, gradual } \\
\text { increase to } 40 \% \mathrm{~h}^{-1} \text { at } \\
35 \mathrm{dph}\end{array}$ & & & & \\
\hline Photoperiod & 12L:12D & & & & \\
\hline Larval food & $\begin{array}{l}\text { Enriched rotifers (5 ind } \\
\mathrm{ml}^{-1} \text { ), }\end{array}$ & $\begin{array}{l}\text { Enriched Artemia } \\
\text { Instar II (0.5-1.0 } \\
\left.\text { ind } \mathrm{ml}^{-1}\right)\end{array}$ & Artificial feed & $\begin{array}{l}\text { Daily addition of phytoplankton (in order to maintain a } \\
\text { concentration of ca. } 650 \pm 300 \times 10^{3} \text { cells } \mathrm{ml}^{-1} \text { ) for } 15 \\
\text { days after hatching }\end{array}$ & \\
\hline
\end{tabular}

run in TAE $1 \times$ buffer at $100 \mathrm{mV}$ for $30 \mathrm{~min}$. Single bands were gel-purified and sequenced.

Another set of PCRs on genomic DNA were performed with $80 \mathrm{nM}$ solutions of specific primers deduced on obtained sequences, $250 \mathrm{ng}$ of genomic DNA, 2 U of PCR Extender Polymerase Mix (5PRIME, Gaithersburg, MD, USA), $5 \mu \mathrm{l}$ 10× Tuning Buffer, 0,5 $\mathrm{mM}$ dNTPs mix. The PCR was performed with the following conditions: $93^{\circ} \mathrm{C}$ for $3 \mathrm{~min}$ and 10 cycles at $93^{\circ} \mathrm{C}$ for $15 \mathrm{~s}$, annealing at $65^{\circ} \mathrm{C}$ for $30 \mathrm{~s}$ elongation at $68^{\circ} \mathrm{C}$ for $8 \mathrm{~min}$, plus 20 cycles with elongation time increased of $20 \mathrm{~s}$ each cycle. After gel electrophoresis single bands were gel-purified, cloned into pGEM-T Easy Vector (Promega, Milan, Italy), and sequenced.

\section{5' Genome walking}

To clone 5' flanking sequence of the gene, genome walking was carried out with the GenomeWalker Universal Kit (Clontech, Saint-Germain-en-Laye, France) according to the manufacturer's procedure. Briefly, aliquots of genomic DNA $(2.5 \mu \mathrm{g})$ were separately digested overnight with the following blunt-end restriction endonucleases: DraI, $E c o$ RV, PvuII and StuI. After inactivation, the four digested DNA preparations were ligated to the GenomicWalker adaptors. Two rounds of PCR were performed with the BD Advantage 2 PCR kit (Clontech, Saint-Germain-enLaye, France). Adaptor-ligated DNA fragments were used

Table 2 sample timing

\begin{tabular}{llll}
\hline SAMPLES & dph & stage & total weight \\
\hline 1a; 1b; 1c & 6 & Mouth opened - black eyes & $404 \mathrm{mg}$ (wet) \\
\hline 2a; 2b; 2c & 16 & Lipid droplet absorption & $300 \mathrm{mg}$ (wet) \\
\hline 3a; 3b; 3c & 27 & Flexion & $961 \mathrm{mg}$ (wet) \\
\hline 4a; 4b;4c & 33 & Post-flexion & $949 \mathrm{mg}$ (wet) \\
\hline 5a; 5b; 5c & 44 & Dorsal and anal fins & $1 \mathrm{~g}$ (wet) \\
\hline
\end{tabular}

dph: days post hatching as template for primary PCR amplification, with the outer adaptor primer (AP1) and a gene specific 5'-outer primer (Table 3, Genome Walking section). Reactions were run using $0.2 \mu \mathrm{M}$ solution of specific primers, $1 \mu \mathrm{l}$ of template, $1 \mu \mathrm{l}$ of $50 \times$ Advantage 2 Polymerase Mix, $5 \mu \mathrm{l} 10 \times$ Advantage 2 PCR buffer, $0.2 \mathrm{mM}$ dNTPs mix. The amplification protocol consisted of two-step cycle parameters: 7 cycles at $95^{\circ} \mathrm{C}$ for $25 \mathrm{~s}$ and $72^{\circ} \mathrm{C}$ for $3 \mathrm{~min}, 37$ cycles at $94^{\circ} \mathrm{C}$ for $25 \mathrm{~s}$ and $67^{\circ} \mathrm{C}$ for $3 \mathrm{~min}$ plus a final extension at $67^{\circ} \mathrm{C}$ for $7 \mathrm{~min}$. Aliquots $(1 \mu \mathrm{l})$ of 50 -fold diluted primary PCR products were used as template in the secondary PCR amplification, with the nested adaptor primer (AP2) and a nested gene-specific primer (Table 3, Genome Walking section) with the same reactions mix described above. The amplification protocol consisted of two-step cycle parameters: 5 cycles at $95^{\circ} \mathrm{C}$ for $25 \mathrm{~s}$ and $72^{\circ} \mathrm{C}$ for $3 \mathrm{~min}, 24$ cycles at $94^{\circ}$ $\mathrm{C}$ for $25 \mathrm{~s}$ and $67^{\circ} \mathrm{C}$ for $3 \mathrm{~min}$ plus a final extension at $67^{\circ}$ $\mathrm{C}$ for $7 \mathrm{~min}$. Amplified products were analyzed in 1\% agarose gel and sequenced as above reported.

\section{Endonucleases digestion}

The $3 \mathrm{~Kb}$ PCR product obtained with the primers Int1a/ 1c_Fwnew and Int1a/1c_REV_5 was very tricky in cloning and sequencing steps because of the presence of highly repeated region. For these reasons a blunt digestion, with $1 \mathrm{U}$ of HaeIII/1 $\mu \mathrm{g}$ of PCR product, was performed in order to obtain smaller fragments. The reaction was incubated at $37^{\circ} \mathrm{C}$ for $2 \mathrm{~h}$. The four bands obtained from the digestion, of $1.5 \mathrm{~Kb}, 1 \mathrm{~Kb}, 0.4 \mathrm{~Kb}, 0.1$ $\mathrm{Kb}$ respectively, were gel purified, A-tailed with DNA Polymerase, ligated into pGEM-T Easy Vector (Promega, Milan, Italy), and sequenced.

\section{RNA extraction, mRNA retro transcription and} amplification

Total RNA was extracted with TRIzol Reagent (Invitrogen, S. Giuliano Milanese, MI, Italy) from about $100 \mathrm{mg}$ 
Table 3 primers used in this paper

\begin{tabular}{|c|c|c|c|c|}
\hline & NAME & SEQUENCE 5'-3' & $\mathrm{Tm}^{\circ} \mathrm{C}$ & Notes \\
\hline \multirow[t]{9}{*}{ Genome Walking } & 1beta_SP1 & CCACTGAGTCCAACCCTTCCAGCAATGC & 72.2 & 3 \\
\hline & 1beta_SP2 & ACCATTTTCCCCTACGCTGTCCTGGAGATAG & 70.2 & 3 \\
\hline & 1beta_SP3 & ACTTCTGCTGTGCTCAGTAGATCGCCCACC & 71.9 & 3 \\
\hline & 1beta_SP4 & GGCAAATATCAACAAGCCCGGGTTGTCAG & 72.0 & 3 \\
\hline & 1beta_SP5 & GGCAATCCAAGTTTGTGGGGGTACTAGTTC & 68.3 & 3 \\
\hline & 1beta_SP6_A & GAGTGTTAACTCCCTCTTTGGCGAGGGG & 69.7 & 3 \\
\hline & 1beta_SP6_B & GGCCTATTACGCATACGCACAAACTGGTC & 69.0 & 3 \\
\hline & AP1 & GTAATACGACTCACTATAGGGC & 59.0 & 4 \\
\hline & AP2 & ACTATAGGGCACAGCGTGGT & 71.0 & 4 \\
\hline \multirow[t]{26}{*}{ Genomic PCR } & Dl_ex1beta_fw & CCAAGTGGTGGGCGATC & 57.6 & 2 \\
\hline & Dl_ex1c_fw & CCATGCAATTTCCACCATC & 54.5 & 2 \\
\hline & DI_ex1a_fw & GTTAACTITGGGAAATGCAAG & 54.0 & 2 \\
\hline & DI_P1_ant_BDNF & CCATAGTAACGAACAGGATG & 55.3 & 2 \\
\hline & DI_P2_ant_BDNF & GTCATCACTCTTCTAACCTGTTG & 58.9 & 2 \\
\hline & DI_ex1a_rev & CACTTGCATTTCCCAAAGTTAAC & 54.0 & 2 \\
\hline & DI_exic_rev & GATGGTGGAAATTGCATGG & 54.5 & 2 \\
\hline & Int1c/2_FW & CCAGACAGTTCTGTATTGTTGTITGGAGGGG & 70.2 & 3 \\
\hline & Int1c/2_REV & TCCAGCCATGTGAGGATCAATTGTGAACGG & 73.6 & 3 \\
\hline & Int1c/2_up & GTATTITCTTAATTGCACACAGCGTGGGTGGG & 71.4 & 3 \\
\hline & Int1c/2_low & CATTCTTAATTGGTATCTGGGGCCGTGGC & 71.0 & 3 \\
\hline & Int1c/2_FWnew & CTCTAGGTGCGTTGTCATGCACAAAGGC & 69.8 & 3 \\
\hline & Int1c/2_REVnew & AGGGGTAATATTGCAGTAGCAGGGGGTGG & 70.0 & 3 \\
\hline & Int1a/1c_FW & ATGCTCCCAATATGGGACCTTAAGACGCTGC & 72.2 & 3 \\
\hline & Int1a/1c_FWnew & GTAATCGTTGCGTTGTGCTTAATCATGCTCC & 66.8 & 3 \\
\hline & Int1a/1c_FW1 & GGTCTGCTGCATTCATGTITTGTCTTGATG & 68.7 & 3 \\
\hline & Int1a/1c_FW2 & GCCCTACTCTTTACCCCCCCCACCC & 70.2 & 3 \\
\hline & 1crev_SP1 & TCTCCCGACAAGCTTCAGGATATCTCTTCAGC & 70.8 & 3 \\
\hline & Int1a/1c_REV_1 & TTTGCGTAACIGCGCGTCTCCACCAIGTC & 74.5 & 3 \\
\hline & Int1a/1c_REV_2 & CAAACTCCTGGATATGAGCTTAAAGGAGGC & 66.4 & 3 \\
\hline & Int1a/1c_REV_3 & CGTTTGGCATGTAGCAGTATGGGAGTGG & 69.3 & 3 \\
\hline & Int1a/1c_REV_4 & CCTITCAAGGCTTCTCTTGCCAAATGC & 68.2 & 3 \\
\hline & Int1a/1c_REV_5 & CATCCTGCCAGCATGTGCAACTGC & 69.6 & 3 \\
\hline & Int1a/1c_REV_6 & CCTGACTCACTITTAGCCTATCTGACATGCAGG & 69.3 & 3 \\
\hline & Int1a/1c_REV_7 & CACACACACACACACACACACACACTGTG & 68.3 & 3 \\
\hline & Int1beta_FW & GACCAGTTTGTGCGTATGCGTAATAGGCC & 69.0 & 3 \\
\hline \multirow[t]{5}{*}{ 3'-RACE } & SP1FW_3' & GGCTGCAGAGGAATAGACAAGCGGCAT & 70.4 & 3 \\
\hline & SP2FW_3' & CCAATGCAGGACAACCCAGTCCTACGT & 69.3 & 3 \\
\hline & BDNF_3'race & GACCATTAAGAGGGGCAGATAG & 60.3 & 3 \\
\hline & $\mathrm{AP}$ & GGCCACGCGTCGACTAGTACTIIITIITIITIIIIIT & 71.1 & 4 \\
\hline & UAP & CUACUACUACUAGGCCACGCGTCGACTAGTAC & 64.3 & 4 \\
\hline \multirow[t]{5}{*}{$5^{\prime}-$ RACE } & RACE_BDNF_GSP1 & CTTGGTTGCTGATCATC & 50.4 & 3 \\
\hline & RACE_BDNF_GSP2 & CTGTGAGTGAGGGCAGTTC & 58.8 & 3 \\
\hline & RACE_BDNF_GSP3 & CGAACAGGATGGTCATCACTC & 59.8 & 3 \\
\hline & AAP & GGCCACGCGTCGACTAGTACGGG\|GGG\|GGG\|G & $>75.0$ & 4 \\
\hline & AUAP & GGCCACGCGTCGACTAGTAC & 66 & 4 \\
\hline \multirow[t]{6}{*}{ RT-PCR } & DI_BDNF_up & ATGACCATCCTGTTCGTTAC & 55.3 & 2 \\
\hline & DI_BDNF_down & CTATCTGCCCCTCTTAATG & 54.5 & 2 \\
\hline & 1beta_FW_nested & GCGAGGGTGTTACGTATATCTG & 58.7 & 3 \\
\hline & 1beta_Rev_new & CCACTCACTCCAACAGATGC & 59.3 & 3 \\
\hline & 1a_FW_new & GCTTATTCTGAGGGAGCCTG & 59.0 & 3 \\
\hline & 1a_Rev_new & CCCAAAGTTAACGCAGTGTG & 59.2 & 3 \\
\hline
\end{tabular}


Table 3: primers used in this paper (Continued)

\begin{tabular}{|c|c|c|c|c|}
\hline & 1bFW & СTCAGCTCTGCAGAGTTGGGGT & 61.8 & 3 \\
\hline & 1c_FW_new & CGTTTCACCATGCGACAAC & 61.1 & 3 \\
\hline & 1c_Rev_new & GCCCAGTCGTAAAACAGACC & 59.6 & 3 \\
\hline & $1 \mathrm{dFW}$ & GTCCTGATGGAAACAGGAAATCAC & 63.1 & 3 \\
\hline & $1 \mathrm{dRev}$ & CACAGATGACGTCTCTTCCAGGT & 62.9 & 3 \\
\hline & Ex2_FW_new & CTTCAGTTGCATGAGAGCTGC & 61.3 & 3 \\
\hline & Ex2_Rev_new & ACCCTCATGCACATATTAGCG & 60.0 & 3 \\
\hline & DI_BDNFreal_low & TTGCTTCAGTTGGCCATTGG & 57.3 & 3 \\
\hline & DI_Act_FW_RT & GGTATTGTCATGGACTCCGGTGAT & 61.9 & 1 \\
\hline & Dl_Act_Right & TTAGAAGCATTTGCGGTGGA & 58.0 & 1 \\
\hline & D.I_GAPDH_FW & GAGGGTGACAAGCTGGTCGT & 58.8 & 1 \\
\hline & D.I.GAPDH_Rev & CAAAGATGGAGGAGTGAGTGTCAC & 58.8 & 1 \\
\hline \multirow[t]{2}{*}{ Universal Primers } & $\mathrm{T7}$ & TAATACGACTCACTATAGGG & 53.2 & \\
\hline & SP6 & CATTTAGGTGACACTATAG & 50.2 & \\
\hline
\end{tabular}

1 - primers deduced on sequences available in public databases (Actin: AY148350; GAPDH: AY863148). 2 - primers deduced on ortologue sequences (BDNF: Danio rerio AL935207 clone CH211-251J8; Fugu rubripes http://www.fugu-sg.org/ scaffold_1; Paralichthys olivaceus AY074888). 3 - primers deduced on obtained sequences. 4 - primers included in the kits used during the experiments.

of each pool of larvae and tissue following the manufacture's instruction, then treated with DNase (DNA free, Ambion, Austin, TX, USA). The first strand cDNA was synthesized using $2 \mu \mathrm{g}$ of total RNA, $150 \mathrm{pmol}$ random primers (for larvae's RNA) and dT16 primer (for tissues' RNA), $1 \mu \mathrm{l}$ dNTPs mix $10 \mathrm{mM}$, in a volume of $12 \mu \mathrm{l}$. The mix was heated at $65^{\circ} \mathrm{C}$ for $15 \mathrm{~min}$, chilled on ice and then $4 \mu \mathrm{l} 5 \times$ retrotranscription buffer, $2 \mu \mathrm{l}$ of $0.1 \mathrm{M}$ DTT, $1 \mu \mathrm{l}$ RNaseOUT and $200 \mathrm{U}$ M-MLV retrotranscriptase (Invitrogen, S. Giuliano Milanese, MI, Italy) were added to a final volume of $20 \mu \mathrm{l}$. After incubation at $37^{\circ} \mathrm{C}$ for $50 \mathrm{~min}$, the reaction was stopped at $75^{\circ} \mathrm{C}$ for $15 \mathrm{~min}$. The generated cDNA was stored at $-20^{\circ} \mathrm{C}$.

The open reading frame was obtained by RT-PCR performed with specific primers Dl_BDNF_up and Dl_BDNF_down designed within conserved regions of BDNF coding sequence belonging to other species. The bipartite BDNF transcripts were evaluated, when necessary, by two rounds of PCR with primers deduced on the obtained exon sequences. Reactions were run using $1 \mu \mathrm{M}$ solution of specific primers (Table 1, Qualitative PCR section), $1 \mu \mathrm{l}$ of cDNA, $0.75 \mathrm{U}$ of GoTaq DNA Polymease (Promega, Milan, Italy), $5 \mu \mathrm{l} 5 \times$ Green GoTaq Reaction buffer, $0.2 \mathrm{mM}$ dNTPs mix. The first round PCR was performed with the following conditions: $94^{\circ} \mathrm{C}$ for $3 \mathrm{~min}$ and 34 cycles at $94^{\circ} \mathrm{C}$ for $30 \mathrm{~s}$, annealing at $56^{\circ} \mathrm{C}$ for $30 \mathrm{~s}$, elongation at $72^{\circ} \mathrm{C}$ for $50 \mathrm{~s}$ and final extension at $72^{\circ} \mathrm{C}$ for $4 \mathrm{~min}$. The second round PCR was performed on $1 \mu \mathrm{l}$ of first round PCR product for 30 cycles at the same conditions.

The PCR products were loaded into $1 \%$ agarose gel stained with ethidium bromide and run in TAE $1 \times$ buffer at $100 \mathrm{mV}$ for $30 \mathrm{~min} ; \beta$-actin and GAPDH were used as housekeeping genes. For each sample a set of
PCR has been run without retrotranscription to exclude any genomic contamination.

\section{5' and 3' Rapid Amplification of cDNA Ends (RACE)}

The 5'-RACE was performed according to the method published by Semple-Rowland et al., [36] with slight modifications. Briefly, $1 \mathrm{mg}$ poly- $\mathrm{A}^{+} \mathrm{RNA}$, extracted from seabass brain, was reversed transcribed using 200 U M-MLV reverse transcriptase (Invitrogen, S. Giuliano Milanese, MI, Italy) following the manufactured instruction and using 20 pmol of sequence-specific antisense primer RACE_BDNF_GSP1. The reaction was incubated at $42^{\circ} \mathrm{C}$ for $50 \mathrm{~min}$ and stopped placing the tube on ice; excess primers, dNTPs and buffer were removed using a QIAquick PCR purification kit (Qiagen, Milan, Italy). In the final step of the procedure the DNA was eluted in $30 \mathrm{ml}$ of water. A poly dCTP tail was added to the single-stranded cDNA present using terminal deoxynucleotidyl transferase (Promega, Milan, italy). The mixture was denaturated at $94^{\circ} \mathrm{C}$ for $3 \mathrm{~min}$, chilled on ice, incubated at $37^{\circ} \mathrm{C}$ for $10 \mathrm{~min}$ and stopped at $70^{\circ} \mathrm{C}$ for 10 min; excess of dCTP and buffer was removed as reported above. Second strand cDNA synthesis was carried out using $5 \mathrm{U}$ TaqPolymerase (Qiagen, Milan, Italy), $0.2 \mu \mathrm{M}$ of a poly $\mathrm{d}(\mathrm{G})$ anchor primer (RACE_AAP), $200 \mathrm{mM}$ dNTPs mix and 10× PCR buffer. The reaction was incubated in a thermocycler at the following conditions: $40^{\circ} \mathrm{C}$ for $5 \mathrm{~min}, 72^{\circ} \mathrm{C}$ for $2 \mathrm{~min}$, than the temperature was increased at $80^{\circ} \mathrm{C}$. At this point 0.2 $\mathrm{mM}$ of the nested sequence-specific primer RACE_BDNF_GSP2 and a nested anchor primer RACE_AUAP were added for the amplification at the following conditions: $94^{\circ} \mathrm{C}$ for $1 \mathrm{~min}, 54^{\circ} \mathrm{C}$ for $1 \mathrm{~min}$, $72^{\circ} \mathrm{C}$ for $1 \mathrm{~min}$ (30 cycles), last extension time $72^{\circ} \mathrm{C}$ for $10 \mathrm{~min}$; kept at $4^{\circ} \mathrm{C} .1 \mathrm{ml}$ of a $1: 10$ dilution of the PCR 
products is re-amplified using the nested anchor primer RACE_AUAP and the nested sequence-specific primer RACE_BDNF_GSP3. The PCR cycle parameters were as follow: 8 touchdown cycles with annealing temperature from 58 to $54^{\circ} \mathrm{C}$, than $94^{\circ} \mathrm{C}$ for $1 \mathrm{~min}, 54^{\circ} \mathrm{C}$ for $1 \mathrm{~min}$, $72^{\circ} \mathrm{C}$ for $1 \mathrm{~min}\left(27\right.$ cycles), last extension time $72^{\circ} \mathrm{C}$ for $10 \mathrm{~min}$; kept at $4^{\circ} \mathrm{C}$. The resulting products were run on a $1 \%$ agarose gel, purified, cloned into pGEM-T Easy Vector (Promega, Milan, Italy) and sequenced.

The 3' race was performed with the following protocol: $4 \mu \mathrm{g}$ of total RNA and 10 pmol of Adapter Primer (AP) in a volume of $10 \mu \mathrm{l}$ was incubated at $70^{\circ} \mathrm{C}$ for 10 min. The mix was chilled on ice and then $4 \mu \mathrm{l}$ of $5 \times$ reverse transcription buffer, $2 \mu \mathrm{l}$ of $25 \mathrm{mM} \mathrm{MgCl}_{2}$ solution, $1 \mu \mathrm{l}$ of $10 \mathrm{mM}$ dNTPs mix and $2 \mu \mathrm{l}$ of $0.1 \mathrm{M}$ DTT were added. The mix was incubated at $42^{\circ} \mathrm{C}$ for $5 \mathrm{~min}$ and then $200 \mathrm{U}$ of SuperScript III reverse transcriptase (Invitrogen, S. Giuliano Milanese, Italy) were added. After incubation at $42^{\circ} \mathrm{C}$ for $50 \mathrm{~min}$, the reaction was stopped at $70^{\circ} \mathrm{C}$ for $15 \mathrm{~min}$. The generated cDNA $(2 \mu \mathrm{l})$ was used as template for PCR. The reactions were run using $1 \mu \mathrm{M}$ solution of Universal Amplification Primer (UAP) and gene specific 3'-outer primer (SP1FW_3'), 0.75 U of GoTaq DNA Polymease (Promega, Milan. Italy), $10 \mu \mathrm{l} 5 \times$ Green GoTaq Reaction buffer, $0.2 \mathrm{mM}$ dNTPs mix. The reaction was incubated in a thermocycler at the following conditions: $95^{\circ} \mathrm{C}$ for 2 ' and 30 cycles at $95^{\circ} \mathrm{C}$ for $30 \mathrm{~s}$, annealing depending on the melting temperature of the primers for $30 \mathrm{~min}$, elongation at $72^{\circ} \mathrm{C}$ for $2 \mathrm{~min}$ and final extension at $72^{\circ} \mathrm{C}$ for 6 min. A second round PCR was performed at the same conditions using $1 \mu \mathrm{l}$ of first PCR product, $1 \mu \mathrm{M}$ solution of UAP and a nested gene-specific primer (SP2FW_3', BDNF_3'race). The resulting products were run on a $1 \%$ agarose gel, purified, cloned into pGEM-T Easy Vector (Promega, Milan, italy) and sequenced.

\section{Semiquantitative analysis}

The bipartite BDNF transcripts expression, in control and stressed brain samples, were evaluated by semiquantitative PCR. The reactions were performed with the same specific primers and conditions of qualitative PCR, and normalization was carried out using cytoplasmatic $\beta$-actin (cDNA 1:50 diluted). The PCR products were loaded into $1 \%$ agarose gel and run in TAE $1 \times$ buffer at $100 \mathrm{mV}$ for $30 \mathrm{~min}$. The semiquantitative analysis was carefully performed by BIO-RAD Gel Doc 2000 connected to the software Quantity one ${ }^{\mathrm{Tm}}$ that allowed to determine, in arbitrary units, the fluorescence value of the area of each considered band. After having obtained all the values, we have normalized them with those of $\beta$-actin; than we evaluated the ratio of the "stressed" samples compared to the control ones. In this way, we have avoided differences due to template concentration in the PCR tube. The data were statistically compared using the two tail omoschedastic Student's $t$-test. The significance level was set at $p<0.05$.

\section{Bioinformatic analysis}

BDNF gene exon-intron boundaries were determined by Blast, ClustalW analysis http://blast.ncbi.nlm.nih.gov/ Blast.cgi; http://www.ebi.ac.uk/Tools/clustalw2/index. html and by direct comparison of PCR-amplified sequences with genomic pufferfish http://www.fugu-sg. org/BLAST/Export.htm, zebrafish, human and rodent DNA from the NCBI database (GeneBank accession number: AL935207 clone CH211-251J8; AF411339; AY057907, respectively).

\section{Western-blot analysis}

Brain and liver were extracted from control $(\mathrm{N}=15)$ or stressed animals $(\mathrm{N}=15)$ and immediately frozen in liquid nitrogen. The tissues were mechanically homogenized at $4^{\circ} \mathrm{C}$ using an extraction buffer solution containing $25 \mathrm{mM}$ Tris $\mathrm{HCl}$ ph 7.5, EDTA $1 \mathrm{mM}$, Spermidin 1 mM, PMSF $1 \mathrm{mM}$, IAA $1 \mathrm{mM}$, Soy Bean Trypsin Inhibitor (SBTI), $10 \mu \mathrm{g} / \mathrm{ml}$ Turkey Egg White inhibitor (TEWI). After homogenization $0.1 \%$ Triton X-100 was added and samples were incubated in agitation for 1 hour at $4^{\circ} \mathrm{C}$. Samples were centrifuged for $5 \mathrm{~min}$, at $4^{\circ} \mathrm{C}$ $(10.000 \times \mathrm{g})$ and the soluble fraction (supernatant) of the lysate was collected for Western blot analysis. Total protein content in lysate tissue samples was determined using Bradford assay (Sigma-Aldrich). Samples $(10 \mu \mathrm{g})$ were run in $15 \%$ SDS-PAGE and proteins were transferred onto a nitrocellulose membrane (Protran Nitrocellulose Transfer Membrane, Whatman) using transfer buffer solution [39 mM Glycine, $48 \mathrm{mM}$ Tris- $\mathrm{HCl}$, 0,037\% (v/v) SDS, 20\% (v/v) methanol]. Subsequently, the membrane was stained using Ponceau dye (SigmaAldrich) to check for the complete protein transfer. Membranes were cut at the level of $44 \mathrm{kDa}$ according to protein markers. The two membranes were incubated for 1 hour at room temperature in blocking solution (4\% (v/v) non fat milk powder, $0.05 \%$ Tween-20 in phosphate buffer saline solution). The upper part of the membrane $(>44 \mathrm{kDa})$ was incubated over night $(\mathrm{O} / \mathrm{N})$ at $4^{\circ} \mathrm{C}$ with anti- $\alpha$-tubulin antibody (Sigma-Aldrich, mAB diluited 1:10.000). The lower part of the membrane $(<44$ $\mathrm{kDa})$ was incubated with anti-BDNF antibody (N-20, pAB, Santa Cruz Biotechnology, diluted 1:500). The anti-BDNF antibody recognizes the first 20 N-terminal aminoacids of mature BDNF and therefore is able to detect both the mature and the precursor form of BDNF. Moreover, as the human and seabass mature BDNF are highly homolog (more than 90\%) we have used human BDNF as positive control [37,38]. After O/ $\mathrm{N}$ hybridization with the specific antibody, membranes were incubated with secondary antibodies for 1 hour at room temperature, we used goat anti-mouse HRP (Sigma-Aldrich, dil. 1:20.000) for $\alpha$-tubulin, and goat 
anti rabbit HRP (DakoCytomation, dil. 1:10.000) for BDNF. Finally, membranes were washed with blocking solution and immunoreactive bands were detected using a chemiluminescence system (ECL-advance, Amersham Biosciences).

\section{Densitometry and statistical analysis}

Densitometric analysis of immunoreactive bands was obtained by scanning films at 16-bit level and applying Quantity One software procedures (Biorad). Data were normalized using as internal control the Western blot for the housekeeping gene $\alpha$-tubulin. The ratio ProBDNF vs total-BDNF or matBDNF vs total-BDNF was expressed as \% and obtained with the formula: proBDNF $/($ proBDNF+matureBDNF $) \times 100$. Each set of data was statistically analyzed using Student's $t$-test and one-way ANOVA (Holm-Sidak). The statistical analysis was performed using SigmaStat 3.1 software. A p value of 0.05 was set as the minimal level for statistical significance.

\section{Calculation of test performance}

We considered positive to the proBDNF/totalBDNF test, individuals whose score was $>1 \mathrm{SD}$ with respect to the average value in the normal, non-stressed population. Stressed animals positive to test are true positive $(=\mathrm{a})$, non-stressed animals which tested positive are false positive $(=\mathrm{b})$, stressed animals that tested negative are false negative $(=c)$ while non-stressed animals that tested negative are true negatives $(=\mathrm{d})$. The sensitivity, calculated as $\mathrm{a} /(\mathrm{a}+\mathrm{c})$, measures the proportion of actual positives which are correctly identified as such; and the specificity, calculated as $d /(d+b)$, measures the proportion of negatives which are correctly identified. The positive predictive value is the probability that a test positive is a true positive: $\mathrm{a} /(\mathrm{a}+\mathrm{b})$ and it is the most important measure of a diagnostic method as it reflects the probability that a positive test reflects the underlying condition being tested for. Its value does however depend on the prevalence of the disease, which may vary. The negative predictive value is the probability that a test negative is a true negative: $d /(c+d)$. The negative predictive value is the proportion of individuals with negative test results who are correctly identified.

\section{Results}

\section{Genomic organization of BDNF}

As the gene encoding BDNF in Dicentrarchus labrax (D. labrax) was not described before, we first cloned the entire gene and determined its genomic organization. We used a strategy of cloning each exon separately using PCR primers designed on a consensus sequence inferred from the ortologue sequences of BDNF in Danio rerio (zebrafish), and Fugu rubripes (pufferfish). Zebrafish, pufferfish, and seabass are all teleosts and therefore we expected a similar exon/intron organization of their BDNF gene and closely related sequences. To clone the 5' flanking sequence of the D. labrax BDNF gene, we carried out a genome walking. Finally, to determine the D. labrax BDNF gene exon/intron boundaries and identify the mRNAs transcribed from the gene, we performed a combination of 5' and 3' rapid amplification of cDNA ends (5' and 3' RACE), RT-PCR and bioinformatic analysis.

The gene spans about $15 \mathrm{~Kb}$ and it is organized in 6 exons and 5 introns as reported in Fig. 1A (GeneBank accession number FJ711591). Exons were identified by ClustalW analysis (see methods) as the most highly conserved segments and were all found to be flanked by the typical consensus splice donor (GT) site in eukaryotes. The exons length and position, and their exon/intron junctions are summarized in Table 4. In analogy with zebrafish and pufferfish, also in D. labrax the BDNF coding sequence is contained in the exon 2 and this tract resulted highly conserved with respect to other vertebrate species $(D$. rerio $84 \%, F$. rubripes $91 \%, H$. sapiens $77 \%$, M. musculus $78 \%$, $R$. norvegicus $78 \%$, ). Upstream to the coding exon we have found other five untranslated exons: $1 \beta, 1 \mathrm{a}, 1 \mathrm{~b}, 1 \mathrm{c}$ and $1 \mathrm{~d}$. By aligning these exon sequences with those of the corresponding zebrafish exons, we found an identity of $85 \%, 43 \%$; $82 \%$; $74 \%$ and $82 \%$, respectively. D. labrax BDNF transcripts analysis indicated that upstream untranslated exons can be spliced independently to the major coding exon to form distinct bipartite BDNF transcripts with different 5 ' UTR lengths and a common coding region (GeneBank accession number DQ915807). Interestingly, in the exons $1 \mathrm{~d}, 1 \mathrm{~b}$ and $1 \beta$ we have identified in-frame ATG codons that could be used as translation start sites leading to the prepro-BDNF proteins with longer $\mathrm{N}$-termini (Fig. 1B).

The five exons located upstream to the coding region did not show any significant identity when aligned with mammalian BDNF genes (rat, mouse and human) with the exception of a $75 \%$ identity between D. labrax exon $1 \beta$ and mammalian exon 1 , and for the presence of the highly conserved segments HCS1, HCS2 and HCS3. HCS2 is located in D. labrax BDNF exon 1a and mammalian exon IIC and showed $96 \%$ identity; HCS1 in D. labrax BDNF exon 1c showed $38-41 \%$ identity with a similar sequence in mouse, rat and human exon IV while the HCS3 is localized in the 3'UTR of D. labrax, mouse, rat and human BDNF and was 97\% identical (39 of 41 nucleotides are identical in fish and man) between these species (Fig. 2 and 3).

The coding region encoded a protein precursor (Fig. 4A) with a signal peptide at the $\mathrm{N}$-terminus, the propeptide of 150 amino acids (AA) in the center and the mature BDNF of 129 amino acids at the C-terminus. This organization is similar to that of zebrafish [39] 


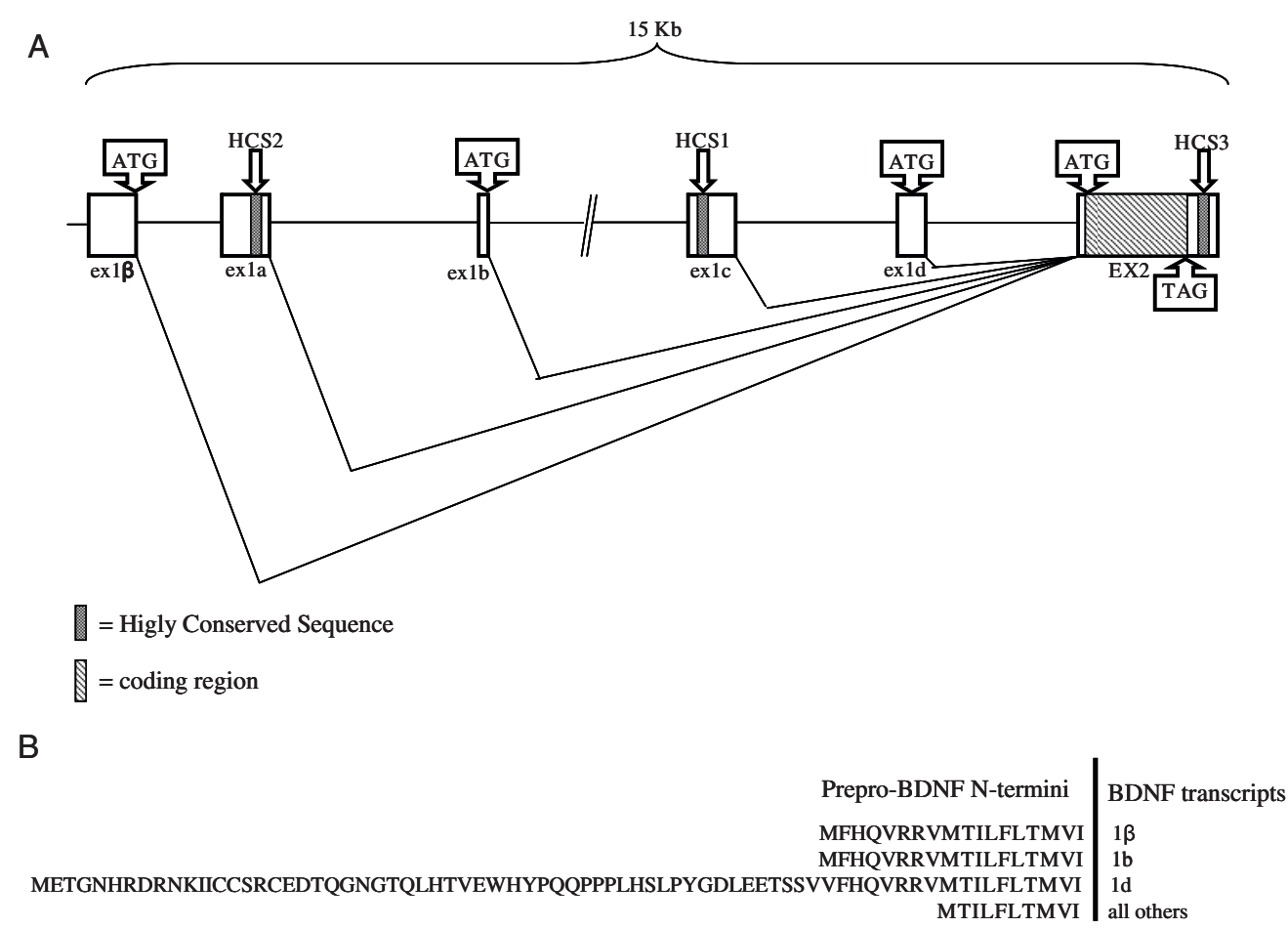

Figure 1 Gene organization and amino acid sequence of BDNF. Panel A. Organization of BDNF gene in Dicentrarchus labrax. Exons are shown as boxes and introns as lines. Alternative start codons (ATG) as well as stop codon (TAG) were reported. Panel B. Amino acid sequences of different potential prepro-BDNF N-termini. Amino acids encoded by exon 2 are in bold and sequences encoded by alternative in frame ATG are in normal style. The transcripts encoding the respective $\mathrm{N}$-termini of BDNF (i.e., 1 $\beta, 1 \mathrm{~b}, 1 \mathrm{~d}$ ) are listed adjacent to the $\mathrm{N}$-terminal sequences.

avian [40] and mammalian BDNF [41-43]. The proBDNF resulted only $87 \%$ identical to zebrafish BDNF and $74-75 \%$ to the mammalian counterparts. However, two regions were $>95 \%$ identical (Fig. 4B): the first 20 $\mathrm{N}$-terminus AA, comprising the signal peptide, and 35 AA just upstream of the cleavage site which also encoded for the glycosilation consensus site (Fig. 4A). Analysis of the extended $\mathrm{N}$-terminal sequences with the prediction programme SignalP 3.0 [44] showed that the

Table 4 Structure of Dicentrarchus labrax gene*

\begin{tabular}{cccccc}
\hline Exon & Start & Splice acceptor & End & Splice donor & $\begin{array}{c}\text { Length } \\
\text { (bp) }\end{array}$ \\
\hline $1 \beta$ & $\mathrm{nt}$ & - & $\mathrm{nt}$ & GGAAAATGgtaagtag & 282 \\
& 321 & & 602 & & \\
\hline $1 \mathrm{a}$ & $\mathrm{nt}$ & - & $\mathrm{nt}$ & TTGTAAAGgtaagagc & 452 \\
& 1367 & & 1818 & & \\
\hline $1 \mathrm{~b}$ & $\mathrm{nt}$ & - & $\mathrm{nt}$ & ACCTGATGgtaggttt & 46 \\
& 4270 & & 4315 & & \\
\hline $1 \mathrm{c}$ & $\mathrm{nt}$ & - & $\mathrm{nt}$ & AGTAAAAGgtatgtgt & 300 \\
& 8347 & & 8646 & & \\
\hline $1 \mathrm{~d}$ & $\mathrm{nt}$ & - & $\mathrm{nt}$ & CTGTGGTgttatgct & 258 \\
& 11540 & & 11797 & & \\
\hline 2 & $\mathrm{nt}$ & ccctccagTTCCACCA & $\mathrm{nt}$ & & - \\
& 14063 & & 15130 & & 1068 \\
\end{tabular}

* Position numbering is based on gene sequence
$\mathrm{N}$-termini produced by exons $1 \beta$ and $1 \mathrm{~b}$ have poor scores as signal peptides because of the presence of a putative signal anchor, while the very long sequence produced by exon $1 \mathrm{~d}$ does not encode for a signal peptide.

Developmental and tissue-specific expression of BDNF splice variants

To learn more about the possible role of BDNF transcripts in the seabass, we analyzed their expression during post-hatching development and their tissue distribution in the adult. The different transcripts were amplified using 5' exon forward specific primers in combination with a reverse primer located on the exon 2 . Expression of the coding exon 2 was determined using internal primers. When no amplicon was detectable after the first PCR reaction, a second round of PCR was carried out to increase sensitivity. Analysis of BDNF expression at $6,16,27,33$ and 44 days post-hatching (dph) showed that, besides variant $1 \mathrm{~d} / 2$, all BDNF variants were expressed during the entire larval maturation. Of note, variant $1 \mathrm{~d} / 2$ transcript was undetectable at all stages even after the second round PCR. Although this analysis cannot be considered quantitative, it is clear that the generated bipartite transcripts showed striking differences in their expression with $1 \mathrm{c} / 2$ splice variant 


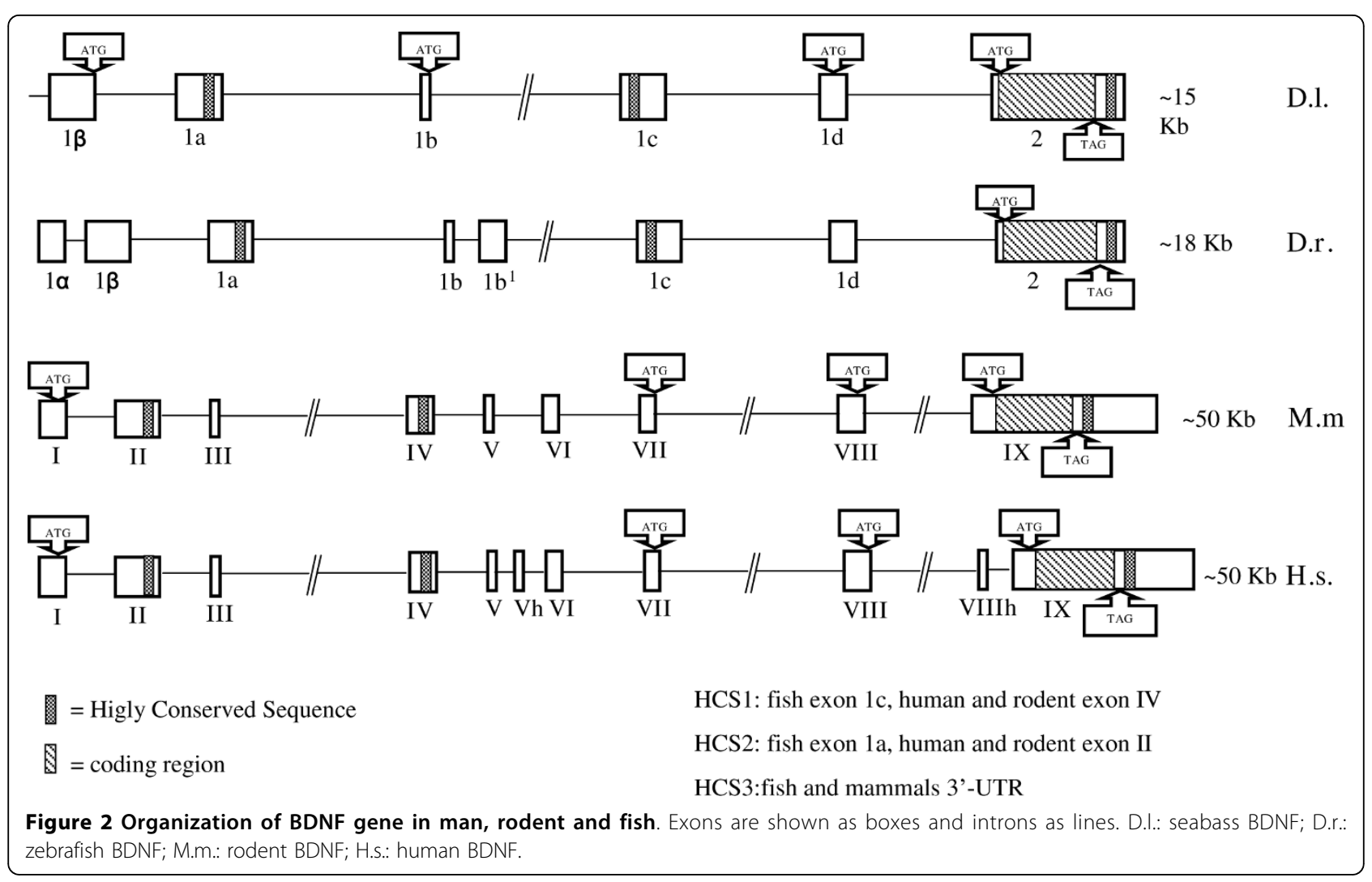

HCS 1

H.S.

АTTACСTCCGCCATGCAАTTTCC---АСTATCAATAАTTTAA 39

R.n./M.m.

АTTACСTCCGCCATGCAАTTTCC---АСТАTCAАTAАTTTAА 39

D.r.

AтTACCTCAACCATGCAATTTCC---ACCATCAATAATTTAA 39

D. labrax

GCAGCCATGGGAGTGCATTACCTCATACCATCAATAATTTAA 42

HCS 2

H.S.

GTTAACTTTGGGAAATGCAAGTGTT 25

R.n./M.m.

GTTAACTTTGGGAAATGCAAGTGTT 25

D.r.

GTTAACTTTGGGAAATGAAGTGTT 25

D. labrax

GTTAACTTTGGGAAATGCAAGTCTT 25

HCS3

H.S.

TATCTATTTGTATATATACATAACAgGgTAAATTATTCAGT 41

R.n./M.m.

TATCTATTTGTATATATACATAACAgGgtAAATTATTCAgT 41

D.r.

TATCTATTTGTATAT--ACATAACAGGGTAAATTATTCAGT 39

D. labrax

TATCTATTTGTATATATACATAACAGGGTAAATTATTCCGT 41

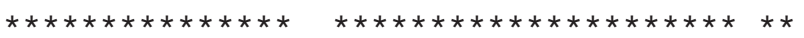

Figure 3 Alignment of Highly Conserved Sequence in man, rodent and fish. (H.s) Homo sapiens, (R.n.) Rattus norvegicus, (D.r.) Danio rerio, (D. I.) Dicentrarchus labrax. 


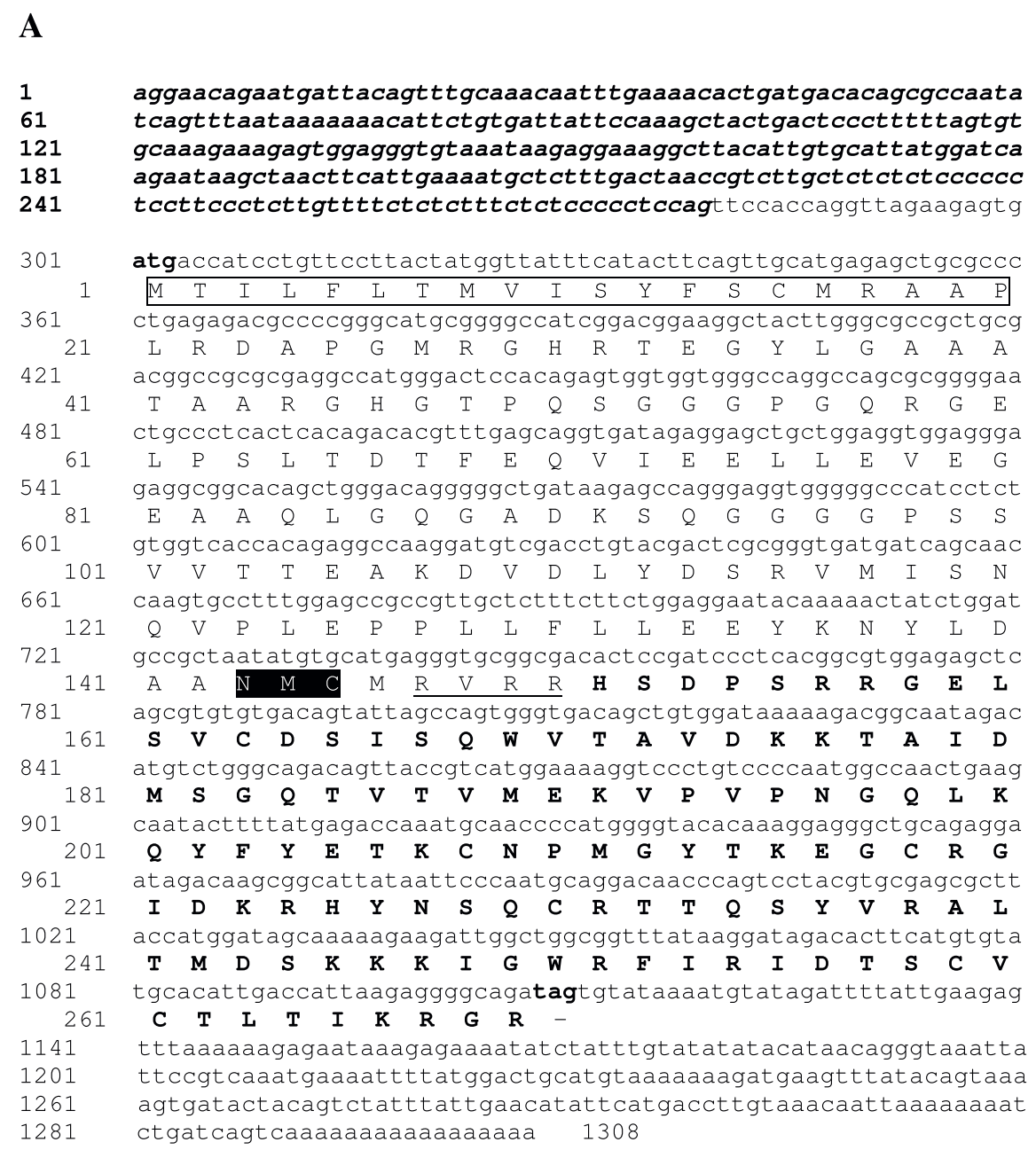

M C: consensus sequence for $\mathrm{N}$-glycosilation

B

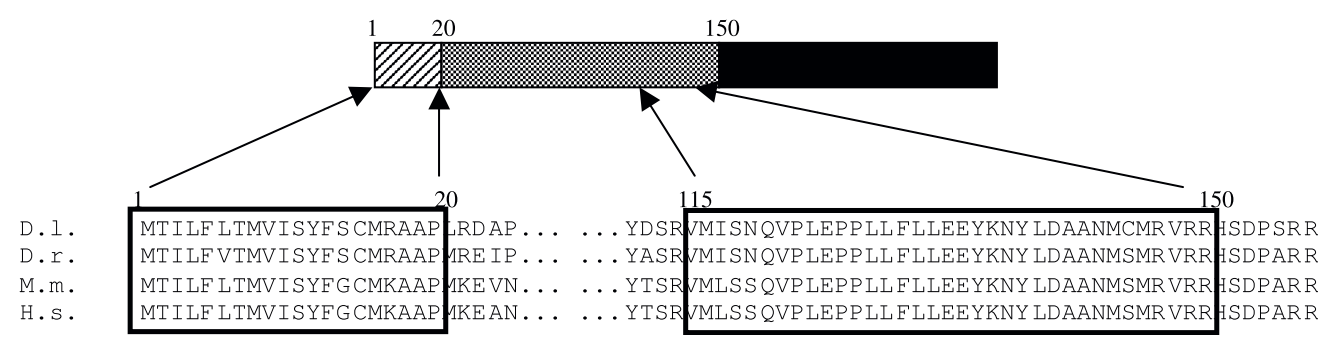

Figure 4 Protein and CDNA sequence of BDNF. Panel A. Dicentrarchus labrax CDNA sequence and deduced amino acid sequence (GeneBank accession number genFJ711591FJ711591). AA sequence of signal peptide is boxed in white; AA sequence for N-glycosilation is boxed in black; The cleavage sequence is underline; start codon and the mature BDNF are shown in bold. Panel B. Representation of the entire BDNF protein and alignment, among different species, of AA sequence of two conserved regions in the prepro protein: Dicentrarchus labrax (D.I.); Danio rerio (D.r.); M.m. Mus musculus; Homo sapiens (H.s). The dashed, the stippled and the black areas correspond to the signal peptide, the propeptide and mature secreted protein respectively. 
showing the highest expression throughout all posthatching development stages (Fig. 5).

Expression of splice variants was also determined in brain, liver, kidney and muscle of adult animals. An example of the PCR analysis, after gel electrophoresis, is shown in Fig. 6. The highest expression levels of the $D$. labrax BDNF transcripts were observed in the brain even though some variants, such as $1 b / 2$ and $1 c / 2$, were detected also in non neuronal tissues even if only after a second round of PCR. A semi-quantitative evaluation of the tissue-specific expression of D. labrax BDNF alternative transcripts is reported in Table 5. Bioinformatic promoter analysis using $\operatorname{Transfac}^{\circ} 6.0$ and public version of Match $^{\text {Tx }}$ software $[45,46]$ highlighted two regions (TGACGTCA and TGAAGTCA), upstream to the exon 1c with highly conserved consensus for the cAMP/calcium responsive element binding protein (CRE) which are also found in mammals upstream to the exon IV [47-50]. The presence of the HCS1 in fish exon 1c and mammalian exon IV supports the likelihood that these two exons are true orthologs.

\section{Effects of acute stress on the expression of BDNF splice} variants

Since acute stress induces variations in BDNF transcripts expression in the brain of rodents $[14,17,15]$ we investigated if any changes occurs when fishes underwent to a brief stressful event consisting in 30 minutes of controlled water deprivation condition (see

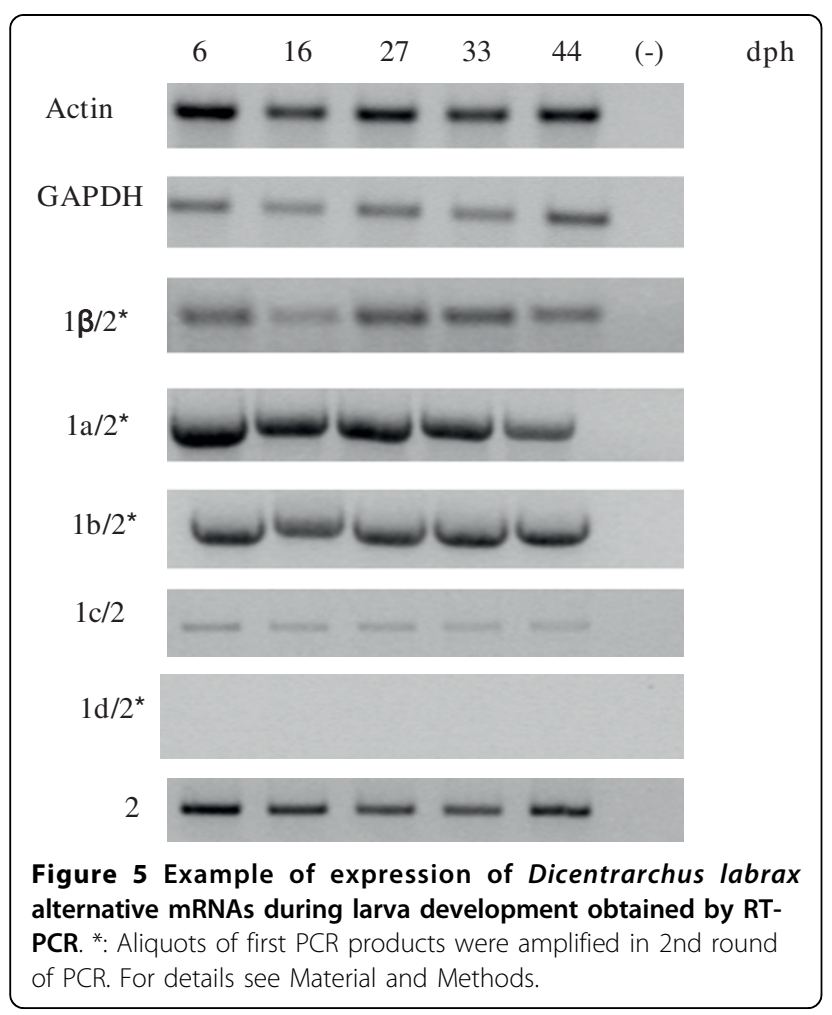

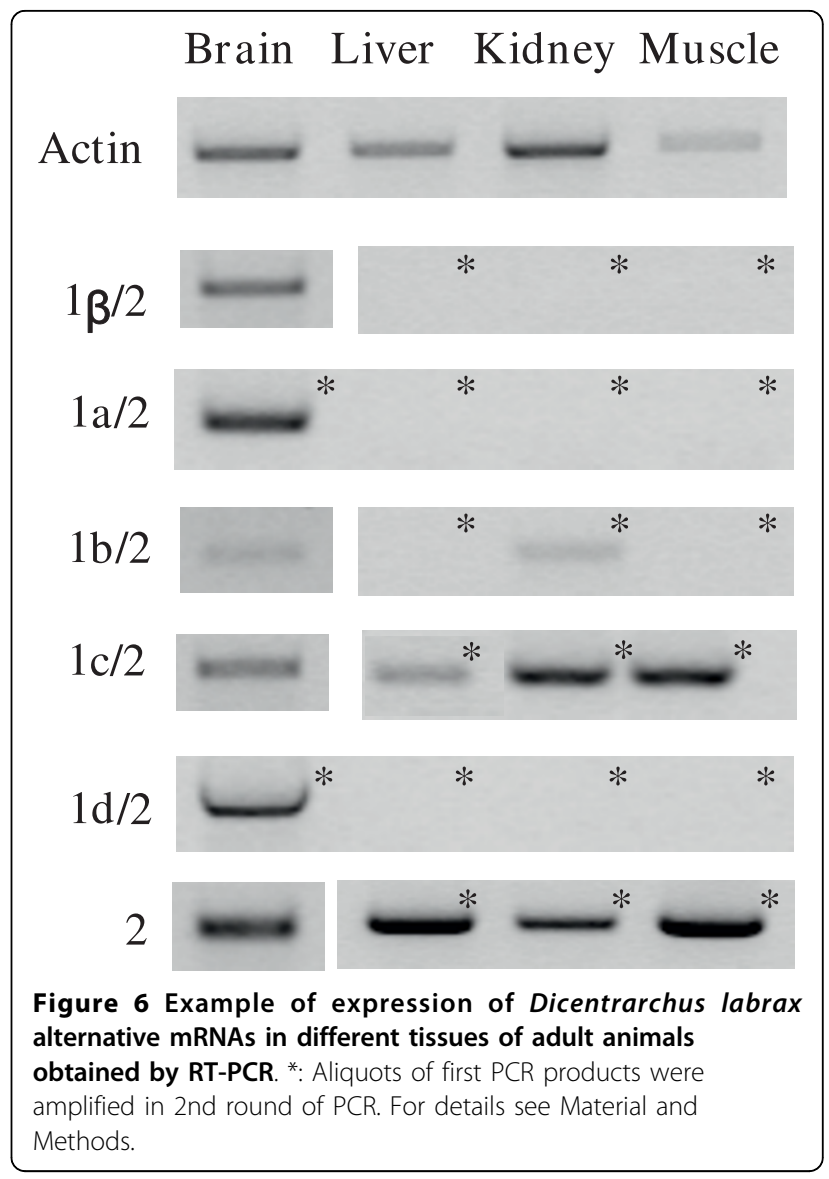

methods). Semi-quantitative PCR analysis of BDNF transcripts expression in the seabass brain revealed that in the stressed group there were no significant differences in the expression of coding exon 2 , and in the upstream exons $1 \beta, 1 \mathrm{a}, 1 \mathrm{~b}$ compared to the control group (Fig. 7). In contrast, we found a significant decrease in the expression of the exons $1 \mathrm{c}$ and $1 \mathrm{~d}(\mathrm{p}<$ 0.05; Fig. 7). Thus, acute stress in the seabass, in absence of an emotional component, induces a rapid down regulation of the exons belonging to the second exon cluster.

Table 5 Expression of $5^{\prime}$ non coding and coding exons in different tissues of adult $D$. labrax

\begin{tabular}{lllll}
\hline EXON & BRAIN & LIVER* & KIDNEY* & MUSCLE* \\
\hline $1 \beta / 2$ & + & n.d. & n.d. & n.d. \\
\hline $1 \mathrm{a} / 2$ & $+^{*}$ & n.d. & n.d. & n.d. \\
\hline $1 \mathrm{~b} / 2$ & $+/-$ & n.d. & $+/-$ & n.d. \\
\hline $1 \mathrm{c} / 2$ & + & $+/-$ & + & + \\
\hline $1 \mathrm{~d} / 2$ & $+^{*}$ & n.d. & n.d. & n.d. \\
\hline 2 & ++ & + & + & + \\
\hline
\end{tabular}

* An aliquot of first PCR product was amplified in a 2 nd round of PCR n.d.: not detectable 

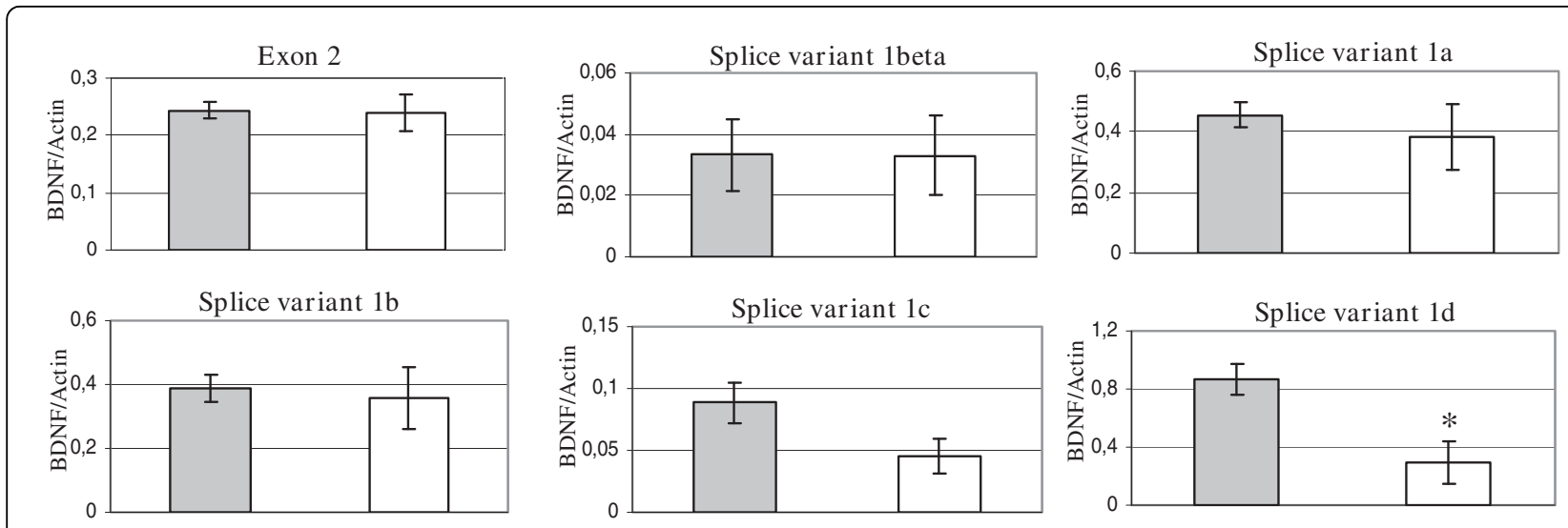

$* \mathrm{p}<0.05$

Figure 7 Histogram of semiquantitative-PCR of BDNF. Variants and coding exon in control are reported as grey bars, stressed samples are reported as white bars. Values are means \pm SD; ${ }^{*} p<0.05 . n=5$.

BDNF protein processing in seabass after acute stress To understand if acute stress can also alter BDNF protein levels and/or processing, we analysed by Western blot the liver and the brain from 15 normally reared controls and 15 animals that underwent acute stress. In both liver and brain, anti-BDNF antibodies recognized two bands with apparent molecular weight of $27 \mathrm{KDa}$ and $18 \mathrm{KDa}$ which correspond to proBDNF (calculated $\mathrm{Mw}=28,7 \mathrm{KDa}$ ) and mature BDNF (calculated $\mathrm{Mw}=13,3 \mathrm{KDa}$ ), respectively (Fig. 8A and 9A). Remarkably, seabass BDNF does not contain the cleavage site (RGLT) that in mammals is recognized by the Membrane-bound transcription factor site-1 protease (MBTPS1 also known as SKI-1 protease) to generate the pro28KDa-BDNFisoforms after a cleavage at Threonin 57 [51]. Thus, in fishes, there is only a proBDNF (equivalent to mammalian pro32KDa) and a mature BDNF.

Preincubation of the anti-BDNF antibody with the corresponding immunizing peptide, abolished staining of both bands indicating that they represent the seabass BDNF (data not shown). In the liver, BDNF was mostly in the mature form (58\% of total BDNF) nevertheless, there was also a large amount of proBDNF (42\% of total BDNF; Fig. 8A). No statistically significant difference was observed in proBDNF and matBDNF in stressed animal (Fig. 8A, B). Similarly, in the brain, the mature form consisted in $60 \%$ of total BDNF and the proBDNF in $40 \%$ of total BDNF (Fig. 9B). 30 min of acute stress had no effects on the total amount of BDNF in the brain but induced a highly significant increase in the proBDNF levels and a corresponding significant reduction in mature BDNF $(\mathrm{p}<$ 0.01 vs. control, Fig. 9B). The scatter-plot distribution analysis of the two populations showed that in the brain of every animal of the stressed group, the percentage of proBDNF is at least 1 standard deviation (SD) above the mean value of the control group (Fig. 9C). Analogous distribution, but towards lower levels, was also found for mature BDNF (not shown). We further calculated if the measurement of the percentage of proBDNF on total BDNF in the brain could represent a predictive test to identify stressed animals. Therefore, we calculated both sensitivity and specificity which are statistical measures of the performance of a binary classification test (see methods). All stressed animals had ratio of proBDNF/totBDNF above $1 \mathrm{SD}$ from the mean value of controls (15/15 stressed are true positive $=\mathrm{a}$, and $0 / 15$ are false negative $=$ c; see methods), hence the sensitivity of the test is $100 \%$ while the specificity is $87 \%$ due to the presence of two false positives $(2 / 15$ controls are false positive $=b$, thus $13 / 15$ are true negative $=\mathrm{d}$; see methods). The test also had a Positive Predictive Value of $88 \%$ and a Negative Predictive Value of $100 \%$ (see methods). In sum, this test is a perfect exclusion test, which means that all specimen with proBDNF/totBDNF values below $43 \%$ are certainly not stressed. Thus, the brain proBDNF/totBDNF ratio (or its counterpart matBDNF/totBDNF) owing to its remarkable difference between stressed and non-stressed animals represents a highly reliable neurological biomarker capable to detect biological stress in seabass.

\section{Discussion}

This study concerns the first characterization of the BDNF gene in Dicentrarchus labrax and its transcriptional, translational and post-translational regulation 


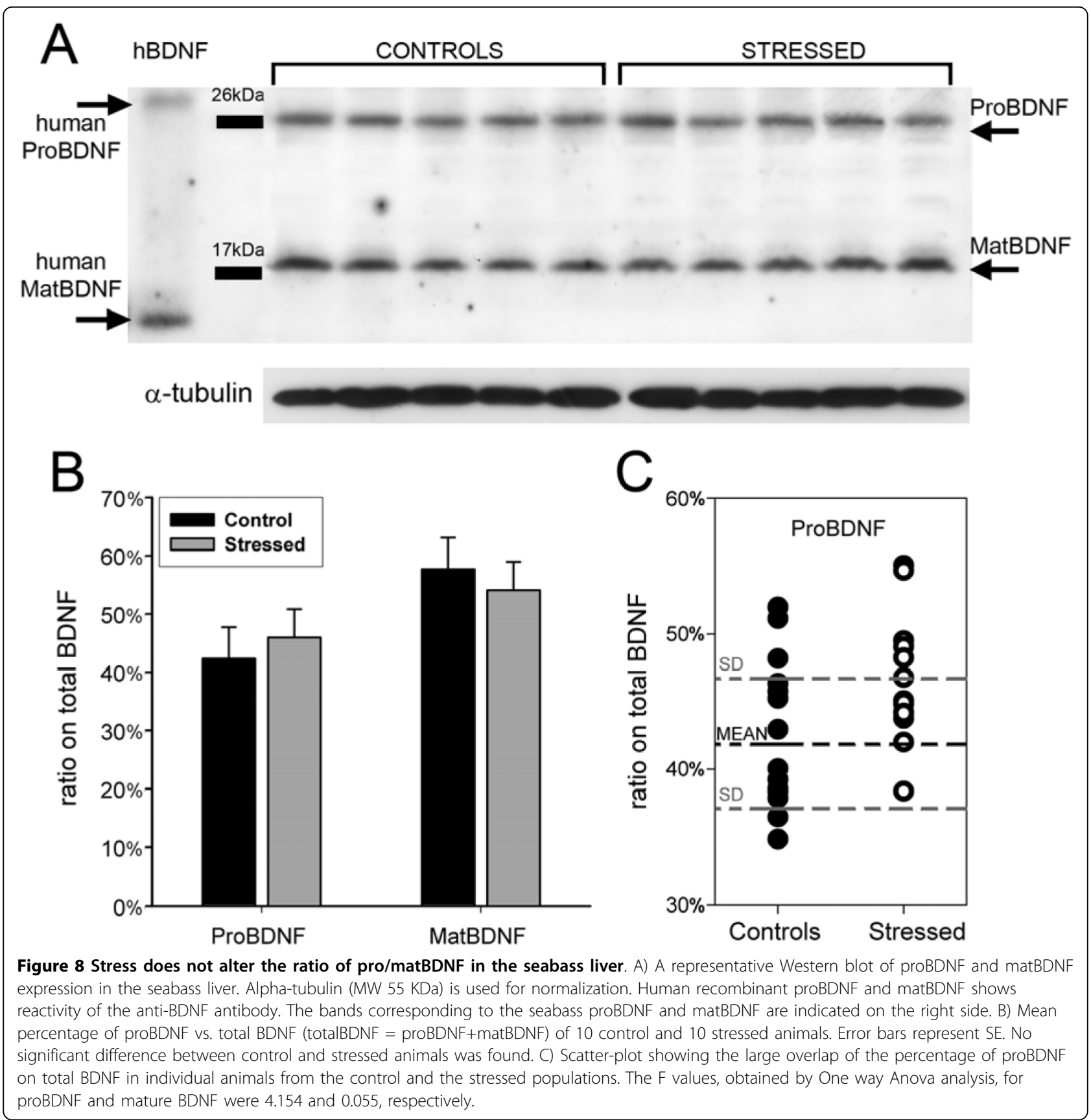

following acute stress. We found that in the seabass, BDNF is highly expressed in the brain and that the transcripts $1 \mathrm{c}$ and $1 \mathrm{~d}$ from the second promoters cluster are down regulated after acute stress. In addition, we show that acute stress induces a significant increase in the proBDNF levels and a corresponding reduction in mature BDNF suggesting altered regulation of proBDNF proteolytic processing. Finally we show that the proBDNF/totBDNF ratio (or its counterpart matBDNF/ totBDNF) is a highly reliable novel quantitative neurological biomarker capable to detect biological stress in fishes with sensitivity $100 \%$, specificity $87 \%$, Positive Predictive Value of $88 \%$ and Negative Predictive Value of $100 \%$.

All known vertebrate BDNF genes share a similar multiple exons organization and encode for a pre-proprotein that is translocated to the endoplasmic reticulum and proteolitically processed to yield the mature protein [52-54]. The D. labrax BDNF gene consists of at least five alternative 5 '-exons and one 3'-coding exon. For what concern the nomenclature, we have referred to previous studies on zebrafish [55] because mammalian, 


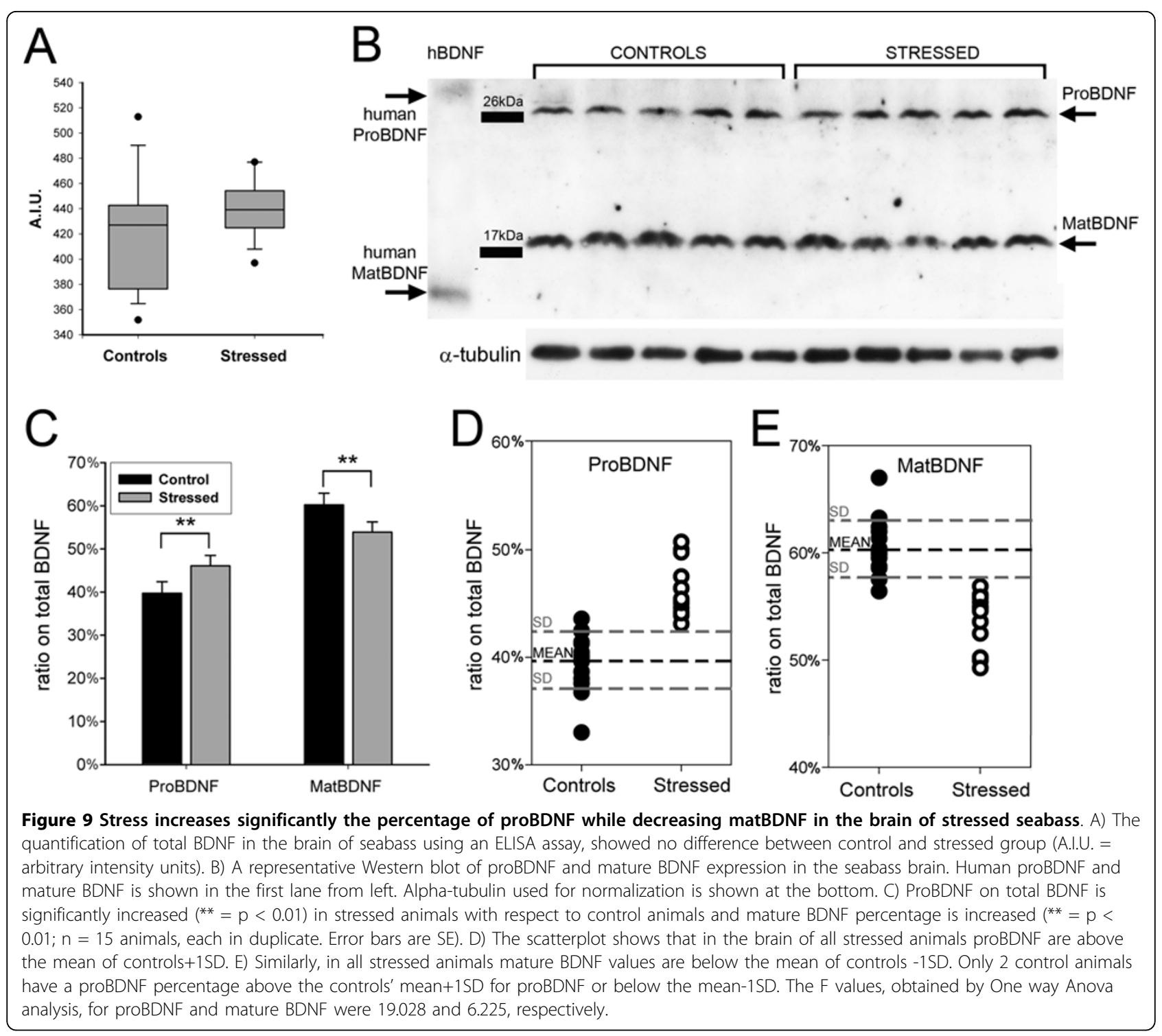

avian and amphibians BDNF follow a different nomenclature [56]. Analysis of D. labrax BDNF transcripts, carried out both in the early developmental stages and in adult tissues, shows that all alternative upstream exons $(1 \beta, 1 \mathrm{a}-1 \mathrm{~d})$ are spliced to the protein-coding exon 2 . This indicates that D. labrax BDNF transcripts structure is similar to other vertebrates. In fact, multiple transcriptional initiation sites and splicing into two-part transcripts can also be found in humans, chimpanzees, dogs, pigs, cats, cows, chicken, frogs, lampreys, zebrafish, and pufferfish [55].

With the exception of the exon 1a (43\%), we found strong sequence homology with zebrafish and pufferfish genes for most exons. Furthermore, exon $1 \beta$ contains $170 \mathrm{nt}$ segment that is highly similar to human exon 1 (75\% identity). Three highly conserved segments were found in the seabass BDNF, HCS2 in exon 1a which is present also in exon IIc of mammalian BDNF; HCS1 in exon $1 \mathrm{c}$ also found in mammalian exon IV while in the 3'UTR encoded by exon 2, we have found the HCS3 which is also present in the 3'UTR in mammals. These results suggest that mammalian exons I, II, and IV (coding for the the 5' untranslated region) evolved early in the vertebrate radiation and may play a major role in BDNF action, while more recently evolved splice variants including other 5 'exons may participate in more specialized functions of BDNF such as, for example, synaptic plasticity. Further research in this direction may allow to test this hypothesis.

The post-hatching developmental analysis indicates that although in different amounts, all D. labrax BDNF transcripts, except $1 \mathrm{~d} / 2$, are well represented at all 
stages analyzed (day post-hatching $6,16,27,33,44$ ). On the other hand, the distribution of various BDNF transcripts in adult seabass is tissue specific with all transcripts being most expressed in the brain. The splice form 1c/2 was also expressed, even though at low levels, in all the examined extra nervous tissues (liver, kidney, muscle), while exon $1 \mathrm{~b} / 2$ transcript was found only in the kidney. Organ-specific expression also holds for most BDNF exons in zebrafish and mammals suggesting conserved transcriptional regulation among the vertebrates [47,52-55].

According to this view, our bioinformatic analysis of D. labrax BDNF gene suggests that the region upstream to exon 1c contains two potential responsive elements, belonging to the CRE family. These elements function as responsive elements also in BDNF exon IV of rat cortical neurons $[47,55]$ and may be responsible of the higher expression of the isoform $1 \mathrm{c} / 2$ in adult seabass tissue. Of note, a previous study on transcriptional analysis of Zebrafish HCS1 reported that this highly conserved sequence in the 5' exon 1c (and vertebrate exon IV) has properties of a dehancer and, depending on the sequence context, as an enhancer [55].

In the second part of our study we have examined the expression of BDNF transcripts after acute stress caused by water deprivation for 30 minutes. Although no significant difference was found in the total BDNF mRNA levels between stressed and control groups (measured by analysis of the protein-coding exon 2 , common to all transcripts), we found a significant decrease in exons 1c and $1 \mathrm{~d}$. This finding is consistent with data in rodents in which single immobilization stress induces down regulation of exon IV, omologous to fish exons 1c (they both contain HCS1), due to decreased histone acetylation at this promoter immediately after acute stress [17]. Of note, in a recent study we showed that exons of the second promoter clusters (mammalian exons IV-VII, fish 1c-d), are particularly important for cell survival in response to cellular excytotoxic stress in human neuroblastoma cells [57]. Thus, activation of promoters upstream to these exons might related to a rapid adaptative response to various types of stress.

Western blot analysis showed that in brain, but not in liver, proBDNF content is significantly increased in the stressed samples. Mammalian BDNF transcripts produce the well-known $32 \mathrm{kDa}$ propeptide precursor that is cleaved either to pro28KDa or to the mature $14 \mathrm{kDa}$ BDNF forms by two different proteases [58]. Pro28Kda BDNF peptide is not further processed into the mature $14 \mathrm{kDa}$ BDNF form but it represents a true final proteolytic product generated by a specific $\mathrm{Ca}^{2+}$-dependent serine proteinase known as Membrane-Bound Transcription Factor Site-1 protease (MBTFS-1; EC = 3.4.21.112, Alternative names: S1P endopeptidase, Site-1 protease), also known as Subtilisin/kexin-isozyme 1 (SKI-1) [51], while mature 14 KDa BDNF is generated intracellularly by furin [58], or extracellularly by plasmin and matrixmetalloprotease-7 [59]. In contrast, in the seabass we only found two BDNF forms, a proBDNF form corresponding to mammalian pro32 $\mathrm{KDa}$ precursor and a mature BDNF, while the pro28KDa peptide was absent. Comparison of D. labrax BDNF protein with that of rodents and human BDNF, revealed that the mammalian SKI-1 cleavage site at Threonine 57 (ArgGly-Leu-Thr $\downarrow$ ) is absent in fishes and amphibians and has first emerged in reptilians during vertebrates evolution [54]. Limited proteolysis of one inactive precursor to produce active peptides and proteins is a general mechanism to generate biologically diverse products from a single gene. Here, we provide the first evidence that fishes possess a simplified proteolytic regulation of BDNF and that the pro28KDa proteolytic product, whose function remains yet to be determined, is absent at this stage of vertebrates evolution.

We found that acute stress profoundly alters the relative amount of proBDNF and mature BDNF. Our data are suggestive of a lower proteolytic activity to generate mature BDNF and thus, the uncleaved product is accumulated in the seabass brain, but not in liver, immediately after an acute stress. Although, the mechanisms by which stress can prevent efficient conversion of proBDNF into mature BDNF are presently unknown, several recent studies have pointed out that pro32KDa BDNF has a biological function distinct from that of mature BDNF. Both proBDNF precursor and mature BDNF can be released from neurons $[59,60]$. While proBDNF binds only to 75 receptor, mature BDNF displays high affinity to TrkB and lower affinity to p75 [61]. Binding of proBDNF to p75 promotes cell death and attenuates synaptic transmission by inducing long term depression [62,63], while mature BDNF sustains long term potentiation and cell survival $[59,64,65]$. It is therefore conceivable that the shift towards higher proBDNF and lower BDNF level observed after acute stress may have the biological role of attenuating proactive behavior inducing reduced activity in stressed animals. Stress affects the hormonal response in fish in much the same way it does in higher animals. Stress stimulates the hypothalamus, one of the oldest parts of the brain (in evolutionary terms) and is responsible for controlling the most basic functions such as hunger, thirst, sex drive and, in mammals, body temperature; all functions that are mediated also by BDNF. A reduced behavioral activity may thus represent an adaptive response to dangerous situations represented here by shallow waters, to allow for an immediate energy saving and recovery in preparation for future actions. In this context, it is striking that $100 \%$ of animals in our 
experimental stress group showed $>1$ SD increase in proBDNF levels (and corresponding decrease in mature BDNF). A theoretical, optimal prediction test can achieve $100 \%$ sensitivity (i.e. predict all people from the sick group as sick) and $100 \%$ specificity (i.e. not predict anyone from the healthy group). Thus, our test performances will make it feasible to screen for stress even in low prevalence populations, particularly where samples are first pooled before testing.

In conclusion, we have determined the structure of Dicentrarchus labrax BDNF gene, its expression in neuronal and non neuronal tissues, and we have demonstrated that the proBDNF/totBDNF ratio (or its counterpart matBDNF/totBDNF) is a novel quantitative neurological biomarker capable to detect biological stress in fishes with sensitivity $100 \%$, specificity $87 \%$, Positive Predictive Value of $88 \%$ and Negative Predictive Value of $100 \%$.

\section{Conclusion}

The high predictivity of proBDNF/totBDNF ratio for stress in lower vertebrates indicates that processing of BDNF is a central mechanism in adaptation to stress and predicts that a similar regulation of pro/mature BDNF has likely been conserved throughout evolution of vertebrates from fish to man.

\section{Acknowledgements}

We thank Dr. Micaela Antonini for technical assistance. We also thank Dr. Nikos Papandroulakis of the Hellenic Centre for Marine Research (Heraklion, Crete) for seabass larvae and for having hosted C.T. during her stage supported by Cariplo Foundation.

\section{Author details \\ 'Department of Biotechnology and Molecular Science, University of Insubria, Varese-Italy. ${ }^{2}$ Department for Life Sciences, BRAIN Centre for Neuroscience, University of Trieste, Trieste-Italy. ${ }^{3}$ Centro di Ricerca Interuniversitario Politecnico di Milano e Università dell'Insubria "The Protein Factory", Italy.}

\section{Authors' contributions}

$C T$ carried out most of the molecular biology experiments, FR participated in the molecular biology experiments, FDC carried out western blot analysis, GB participated in the western blot analysis, ET designed the western blot experiments and participated to draft the manuscript, GT and MS designed and carried out animal treatment and sacrifice, GB and RG conceived the study, designed and coordinated molecular biology experiments and drafted the manuscript. All authors read and approved the final manuscript.

Received: 2 September 2009

Accepted: 14 January 2010 Published: 14 January 2010

\section{References}

1. Casaccia-Bonnefil P, Gu C, Chao MV: Neurotrophins in cell survival/death decisions. Adv Exp Med Bio 1999, 468:275-282.

2. Huang EJ, Reichardt LF: Neurotrophins: roles in neuronal development and function. Annu Rev Neurosci 2001, 24:677-736.

3. Poo MM: Neurotrophins as synaptic modulators. Nat Rev Neurosci 2001, 2:24-31.

4. McAllister AK, Katz LC, Lo DC: Neurotrophins and synaptic plasticity. Annu Rev Neurosci 1999, 295-318.
5. Thoenen H: Neurotrophins and activity-dependent plasticity. Prog Brain Res 2000, 128:183-191.

6. Bramham CR, Messaoudi E: BDNF function in adult synaptic plasticity: the synaptic consolidation hypothesis. Prog Neurobiol 2005, 76:99-125.

7. Lu Y, Christian K, Lu B: BDNF: a key regulator for protein synthesisdependent LTP and long-term memory?. Neurobiol Learn Mem 2008, 89:312-323.

8. Bramham CR: Control of synaptic consolidation in the dentate gyrus: mechanisms, functions, and therapeutic implications. Prog Brain Res 2007, 163:453-471

9. Marini AM, Popolo M, Pan H, Blondeau N, Lipsky RH: Brain adaptation to stressful stimuli: a new perspective on potential therapeutic approaches based on BDNF and NMDA receptors. CNS Neurol Disord Drug Targets 2008, 7:382-390.

10. Smith MA, Makino S, Kim SY, Kvetnansky R: Stress increases brain-derived neurotropic factor messenger ribonucleic acid in the hypothalamus and pituitary. Endocrinology 1995, 136:3743-3750.

11. Smith MA, Makino S, Kvetnansky R, Post RM: Effects of stress on neurotrophic factor expression in the rat brain. Ann N Y Acad Sci 1995, 771:234-239.

12. Smith MA, Makino S, Kvetnansky R, Post RM: Stress and glucocorticoids affect the expression of brain derived neurotrophic factor and neurotrophin-3 mRNAs in the hippocampus. J Neurosci 1995, 15:1768-1777.

13. Nibuya M, Takahashi M, Russell DS, Duman RS: Repeated stress increases catalytic TrkB mRNA in rat hippocampus. Neurosci Lett 1999, 267:81-84.

14. Marmigère $F$, Givalois $L$, Rage F, Arancibia S, Tapia-Arancibia L: Rapid induction of BDNF expression in the hippocampus during immobilization stress challenge in adult rats. Hippocampus 2003, 13:646-655.

15. Nair A, Vadodaria KC, Banerjee SB, Benekareddy M, Dias BG, Duman RS, Vaidya VA: Stressor-Specific Regulation of Distinct Brain-Derived Neurotrophic Factor Transcripts and Cyclic AMP Response ElementBinding Protein Expression in the Postnatal and Adult Rat Hippocampus. Neuropsychopharmacology 2007, 32:1504-1519.

16. Lee T, Saruta J, Sasaguri K, Sato S, Tsukinoki K: Allowing animals to bite reverses the effects of immobilization stress on hippocampal neurotrophin expression. Brain Res 2008, 1195:43-49.

17. Fuchikami M, Morinobu S, Kurata A, Yamamoto S, Yamawaki S: Single immobilization stress differentially alters the expression profile of transcripts of the brain-derived neurotrophic factor (BDNF) gene and histone acetylation at its promoters in the rat hippocampus. Int $\mathrm{J}$ Neuropsychopharmacol 2009, 12:73-82.

18. Gold PW, Chrousos GP: Organization of the stress system and its dysregulation in melancholic and atypical depression: high vs low CRH/ NE states. Mol Psychiatry 2002, 7:254-275.

19. Brown DW, Balluz LS, Ford ES, Giles WH, Strine TW, Moriarty DG, Croft JB, Mokdad AH: Associations between short- and long-term unemployment and frequent mental distress among a national sample of men and women. J Occup Environ Med 2003, 45:1159-1166.

20. Duman RS, Monteggia LM: A neurotrophic model for stressrelated mood disorders. Biol Psychiatry 2006, 59:1116-1127.

21. Dawkins MS: From an animal's point of view: motivation, fitness, and animal welfare. Behav Brain Sci 1990, 13:1-61.

22. Rasmusson AM, Shi L, Duman R: Downregulation of BDNF mRNA in the Hippocampal Dentate Gyrus after Re-exposure to Cues Previously Associated with Footshock. Neuropsychopharmacology 2002, 27:133-142.

23. Gasic GP, Smoller JW, Perlis RH, Sun M, Lee S, Kim BW, Lee MJ, Holt DJ, Blood AJ, Makris N, Kennedy DK, Hoge RD, Calhoun J, Fava M, Gusella JF, Breiter HC: BDNF, relative preference, and reward circuitry responses to emotional communication. Am J Med Genet B Neuropsychiatr Genet 2009, 150:762-781.

24. Roche H, Bogé G: Fish blood parameters as a potential tool for identification of stress caused by environmental factors and chemical intoxication. Marine Env Res 1996, 41:27-43.

25. Gornati R, Terova G, Vigetti D, Prati M, Saroglia M, Bernardini G: Effects of population density on seabass (Dicentrarchus labrax) gene expression. Aquaculture 2004, 230:229-239.

26. Korte SM, Olivier B, Koolhaas JM: A new animal welfare concept based on allostasis. Physiol Behav 2007, 92:422-428. 
27. Gornati R, Papis E, Rimoldi S, Terova G, Saroglia M, Bernardini G: Rearing density influences the expression of stress related genes in seabass (Dicentrarchus labrax, L.). Gene 2004, 341:111-118.

28. Gornati R, Papis E, Rimoldi S, Chini V, Terova G, Prati M, Saroglia M, Bernardini $G$ : Molecular markers for animal biotechnology: sea bass (Dicentrarchus labrax, L.) HMG-CoA reductase mRNA. Gene 2005, 344:299-305

29. Ribas L, Planas JV, Barton B, Monetti C, Bernardini G, Saroglia M, Tort L, Mackenzie S: A differentially expressed enolase gene isolated from the gilthead sea bream (Sparus aurata) under high-density conditions is upregulated in brain after in vivo lipopolysaccharide challenge. Aquaculture 2004, 241:195-206

30. Rimoldi S, Terova G, Brambilla F, Bernardini G, Gornati R, Saroglia M: Molecular characterization and expression analysis of $\mathrm{Na}^{+} / \mathrm{H}^{+}$exchanger (NHE)-1 and c-Fos genes in sea bass (Dicentrarchus labrax, L) exposed to acute and chronic hypercapnia. J Exp Mar Biol Ecol 2009, 375:32-40.

31. Terova G, Gornati R, Rimoldi S, Bernardini G, Saroglia M: Quantification of a glucocorticoid receptor in sea bass (Dicentrarchus labrax, L.) reared at high stocking density. Gene 2005, 357:144-151.

32. Terova G, Rimoldi S, Brambilla F, Gornati R, Bernardini G, Saroglia M: In vivo regulation of GLUT2 mRNA in sea bass (Dicentrarchus labrax) in response to acute and chronic hypoxia. Comp Biochem Physiol Part $B$ 2009, 152:306-316.

33. Terova G, Rimoldi S, Larghi S, Bernardini G, Gornati R, Saroglia M: Regulation of progastricsin mRNA levels in sea bass (Dicentrarchus labrax) in response to fluctuations in food availability. Biochem Biophys Res Commun 2007, 363:591-596.

34. Terova G, Rimoldi S, Corà S, Bernardini G, Gornati R, Saroglia M: Acute and chronic hypoxia affects HIF-1a mRNA levels in sea bass (Dicentrarchus labrax). Aquaculture 2008, 279:150-159.

35. Terova G, Rimoldi S, Bernardini G, Gornati R, Saroglia M: Sea bass ghrelin: molecular cloning and mRNA quantification during fasting and refeeding. Gen Comp Endocrinol 2008, 155:341-351.

36. Semple-Rowland SL, Larkin P, Bronson JD, Nykamp K, Streit WJ, Baehr W: Characterization of the chicken GCAP gene array and analyses of GCAP1, GCAP2, and GC1 gene expression in normal and rd chicken pineal. Mol Vis 1999, 5:U7-U14.

37. Michalski B, Fahnestock M: Pro-brain-derived neurotrophic factor is decreased in parietal cortex in Alzheimer's disease. Brain Res Mol Brain Res 2003, 111:148-154.

38. Peng S, Wuu J, Mufson EJ, Fahnestock M: Precursor form of brain-derived neurotrophic factor and mature brain-derived neurotrophic factor are decreased in the pre-clinical stages of Alzheimer's disease. J Neurochem 2005, 93:1412-21.

39. Hashimoto $M$, Heinrich $G$ : Brain-derived neurotrophic factor gene expression in the developing zebrafish. Int J Dev Neurosci 1997, 15:983-997.

40. Maisonpierre PC, Belluscio L, Conover JC, Yancopoulos GD: Gene sequences of chicken BDNF and NT-3. DNA Seq 1992, 3:49-54.

41. Hofer M, Pagliusi SR, Hohn A, Leibrock J, Barde YA: Regional distribution of brain-derived neurotrophic factor mRNA in the adult mouse brain. $E M B O$ J 1990, 9:2459-2464.

42. Jones KR, Reichardt LF: Molecular cloning of a human gene that is a member of the nerve growth factor family. Proc Natl Acad Sci USA 1990 87:8060-8064.

43. Maisonpierre PC, Le Beau MM, Espinosa R, Ip NY, Belluscio $L$, de la Monte SM, Squinto S, Furth ME, Yancopoulos GD: Human and rat brainderived neurotrophic factor and neurotrophin-3: gene structures, distributions, and chromosomal localizations. Genomics 1991, 10:558-568.

44. Bendtsen JD, Nielsen H, von Heijne G, Brunak S: Improved prediction of signal peptides: SignalP 3.0. J Mol Biol 2004, 340:783-795.

45. Matys V, Fricke E, Geffers R, Gossling E, Haubrock M, Hehl R, Hornischer K, Karas D, Kel AE, Kel-Margoulis OV, Kloos DU, Land S, Lewicki-Potapov B, Michael H, Munch R, Reuter I, Rotert S, Saxel H, Scheer M, Thiele S, Wingender E: TRANSFAC: transcriptional regulation, from patterns to profiles. Nucleic Acids Res 2003, 31:374-378.

46. Gößling E, Kel-Margoulis OV, Kel AE, Wingender E: MATCHTM-a tool for searching transcription factor binding sites in DNA sequences. Application for the analysis of human chromosomes. Proceedings of the German Conference on Bioinformatics GCB'0;: Braunschweig, Germany 2001.
47. Liu QR, Lu L, Zhu XG, Gong JP, Shaham Y, Uhl GR: Rodent BDNF genes, novel promoters, novel splice variants, and regulation by cocaine. Brain Res 2006, 1067:1-12

48. Chen WG, West AE, Tao X, Corfas G, Szentirmay MN, Sawadogo M, Vinson C, Greenberg ME: Upstream stimulatory factors are mediators of $\mathrm{Ca}^{2+}$-responsive transcription in neurons. J Neurosci 2003, 23:2572-2581.

49. Martinowich $K$, Hattori D, Wu H, Fouse S, He F, Hu Y, Fan G, Sun YE: DNA methylation-related chromatin remodeling in activity-dependent BDNF gene regulation. Science 2003, 302:890-893.

50. Tao X, West AE, Chen WG, Corfas G, Greenberg ME: A calcium-responsive transcription factor, CaRF, that regulates neuronal activity-dependent expression of BDNF. Neuron 2002, 33:383-395.

51. Seidah NG, Mowla SJ, Hamelin JE, Mamarbachi AM, Benjannet S, Toure BB, Basak A, Munzer JS, Marcinkiewicz J, Zhong M, Barale JC, Lazure C, Murphy RA, Tien MC, Marcinkiewicz M: Mammalian subtilisin/kexin isozyme SKI-1 A widely expressed proprotein convertase with a unique cleavage specificity and cellular localization. Proc Natl Acad Sci USA 1999 96:1321-1326.

52. Aid T, Kazantseva A, Piirsoo M, Palm K, Timmusk T: Mouse and rat BDNF gene structure and expression revisited. J Neurosci Res 2007, 85:525-535.

53. Pruunsild P, Kazantseva A, Aid T, Palm K, Timmusk T: Dissecting the human BDNF locus: bidirectional transcription, complex splicing, and multiple promoters. Genomics 2007, 90:397-406.

54. Tettamanti G, Cattaneo AG, Gornati R, de Eguileor M, Bernardini G, Binelli G: Phylogenesis of Brain Derived Neurotrophic Factor (BDNF) in Vertebrates. Gene 2010, 450:85-93.

55. Heinrich G, Pagtakhan CJ: Both $5^{\prime}$ and $3^{\prime}$ flanks regulate Zebrafish brainderived neurotrophic factor gene expression. BMC Neurosci 2004, 5:19-38.

56. Kidane $A H$, Heinrich $G$, Dirks RPH, de Ruyck BA, Lubsen NH, Roubos EW, Jenks BG: Differential Neuroendocrine Expression of Multiple BrainDerived Neurotrophic Factor Transcripts. Neuroendocrinology 2009, 150:1361-1368.

57. Baj G, Tongiorgi E: BDNF splice variants from the second promoter cluster support cell survival of differentiated neuroblastoma upon cytotoxic stress. J Cell Sci 2009, 122:36-43

58. Mowla SJ, Farhadi HF, Pareek S, Atwal JK, Morris SJ, Seidah NG, Murphy RA: Biosynthesis and post-translational processing of the precursor to brainderived Neurotrophic factor. J Biol Chem 2001, 276:12660-12666.

59. Lee R, Kermani P, Teng KK, Hempstead BL: Regulation of cell survival by secreted proneurotrophins. Science 2001, 294:1945-1948.

60. Yang J, Siao CJ, Nagappan G, Marinic T, Jing D, McGrath K, Chen ZY, Mark W, Tessarollo L, Lee FS, Lu B, Hempstead BL: Neuronal release of proBDNF. Nat Neurosci 2009, 12:113-115.

61. Chao MV: Neurotrophins and their receptors: a convergence point for many signalling pathways. Nat Rev Neurosci 2003, 4:299-309.

62. Teng HK, Teng KK, Lee R, Wright S, Tevar S, Almeida RD, Kermani P, Torkin R, Chen ZY, Lee FS, Kraemer RT, Nykjaer A, Hempstead BL: ProBDNF induces neuronal apoptosis via activation of a receptor complex of p75NTR and sortilin. J Neurosci 2005, 25:5455-5463.

63. Woo NH, Teng HK, Siao CJ, Chiaruttini C, Pang PT, Milner TA, Hempstead BL, Lu B: Activation of p75NTR by proBDNF facilitates hippocampal long-term depression. Nat Neurosci 2005, 8:1069-1077.

64. Patterson SL, Abel T, Deuel TA, Martin KC, Rose JC, Kandel ER: Recombinant BDNF rescues deficits in basal synaptic transmission and hippocampal LTP in BDNF knockout mice. Neuron 1996, 16:1137-1145.

65. Pang PT, Teng HK, Zaitsev E, Woo NT, Sakata K, Zhen S, Teng KK, Yung WH, Hempstead BL, Lu B: Cleavage of proBDNF by tPA/plasmin is essential for long-term hippocampal plasticity. Science 2004, 306:487-491.

doi:10.1186/1471-2202-11-4

Cite this article as: Tognoli et al:: Acute stress alters transcript expression pattern and reduces processing of proBDNF to mature BDNF in Dicentrarchus labrax. BMC Neuroscience 2010 11:4. 